\title{
El Primer Siglo del Teatro en Puebla de los Angeles y la Oposición del Obispo don Juan de Palafox y Mendoza
}

\begin{abstract}
A pesar de que las Actas de Cabildo de Puebla de los Angeles A contienen bastantes datos relativos a las representaciones teatrales que ya se registraban en esa población de la Nueva España en el año de 1598 , se ha hecho muy poco uso de ellas. ${ }^{1}$ Otras fuentes de menor información, hasta ahora no aprovechadas, concernientes al mismo asunto, son: las Actas de Cabildo de la Ciudad de México (las cuales mencionaban con frecuencia que las compañias de actores habían ido de la capital a Puebla o que era preciso hacerlas regresar de dicha ciudad a fin de representar comedias para la fiesta del Corpus), el General de patte, Litterae annuae (escritas por los jesuítas a Roma), las dos historias de los padres Andrés Pérez de Rivas y Francisco Javier Alegre, y la Carta del Obispo don Juan de Palafox y Mendoza, dirigida a los curas y sacerdotes de Puebla.

Este estudio comprende los años de 1598 a 1687: comienza a raíz de la aparición del teatro, tímido y balbuciente en los primeros años, con las representaciones destinadas a dar divertimiento durante la fiesta del Corpus Christi; nombra varios autores de comedias (empresarios), actores y actrices y cuenta algo de sus curiosas aventuras; suministra alguna idea de las primeras casas de comedias, citando los nombres de los dueños e indicando los gastos para las funciones teatrales en ese segundo centro cultural de la Nueva España. En cierto sentido los datos aquí recogidos constituyen una revista de los espectáculos públicos, un cuadro de las costumbres de la época virreinal: presentan una fase de la vida nacional, poniendo de manifiesto el desarrollo que ha tenido en el país el gusto público; nos
\end{abstract}


permiten conocer el ambiente moral de esos días, las ideas sociales, las preocupaciones dominantes y el sentimiento religioso que se sentía ofendido por la asistencia de curas y sacerdotes a los espectáculos de teatro. Ignóranse, por desgracia, los títulos de las piezas que entonces solían recitarse y los nombres de los dramaturgos, porque se omitía tal clase de información en las actas. El Cabildo de la ciudad de Puebla nombraba de ordinario a dos o tres de sus regidores para atender a los pormenores de la fiesta del Misterio de la Eucaristía y hacer los arreglos con los empresarios de las compañías de cómicos. El ambiente para dichas festividades en la Muy Noble y Muy Leal Ciudad de los Angeles no podía ser más propicio, pues en tales días prevalecía el espíritu surgido de la Contrarreforma, que originó esa religiosidad activa, de tan notable influencia en la solemnización de las fiestas patrocinadas por la Iglesia. El concilio tridentino (duró de 1545 a 1563) animado por España ejerció notable influjo sobre el desarrollo de la fiesta del Corpus, pues sus resoluciones estimularon efectivamente el cultivo de las representaciones dramáticas en los siglos Xvi y xirr. ${ }^{2}$

En el indicado período de ochenta y nueve años los gastos para las comedias del Corpus eran pagados de los propios de la ciudad. En el año de 1598, por falta de compañía de actores, el Cabildo contrató con el clérigo Rodrigo de Chávez para la representación de la comedia en trescientos pesos de oro común. En 1600 los jesuítas tuvieron dos funciones dramáticas con motivo de la terminación de su nuevo templo y la colocación de reliquias enviadas de Roma. En el año de 1603 los autores de comedias Alonso Velázquez y Gonzalo de Riancho ejecutaron una farsa el día del Corpus por seiscientos cincuenta pesos de oro común; fueron erigidos cuatro tablados para la fiesta. En el mismo año el Virrey dió licencia a los empresarios Antonio Rodríguez y Juan Corral para trabajar en Puebla, estableciendo la regla de que las licencias para la capital no eran válidas para la otra ciudad. En 1613 el carpintero Juan Gómez tuvo que interrumpir las funciones dramáticas, en su casa, so pena de ser multado con doscientos pesos y ver derribado el teatro por orden del Ayuntamiento. La comedia para el Corpus de 1615 fué representada en un tablado levantado en la plaza pública. En el año de 1616 no hubo comediantes y la ciudad tuvo que contentarse con danzas de indios y procesiones para la fiesta del Santísimo Sacramento. En 1618 el regidor Felipe Ramírez, dueño de un teatro en la cuadra 
inmediata a la plaza pública, consiguió licencia para aprovechar la única casa de comedias durante veinte años. A la vez se reveló que usaban en aquel entonces un corral para las funciones teatrales. En dicho año Gonzalo de Riancho estaba de vuelta con su compañía. Los datos relativos a las festividades del Corpus de 1622 muestran que las comedias solían representarse a la puerta de la catedral, delante de la hostia. En 1626 la ciudad, con la esperanza de remediar su mal estado financiero, suplicó al Virrey y obtuvo licencia para fundar un corral por el cual cobraría renta: Juan Antonio de Sigüenza trabajaba con su compañía, en 1630, en Puebla. Dos años después (1632) se hallaban allí dos compañías, una de Ana María de los Angeles y la otra de Hernando Ramos. En 1644 el Obispo don Juan de Palafox y Mendoza rehusó aceptar una invitación para asistir a la representación de dos comedias que iban a darse el día del Corpus y la octava a la puerta de la catedral y prohibió a los clérigos que estuviesen presentes, pareciéndole las comedias inmorales y dañosas. Además, vedó que se colocasen tablados én la parte sagrada de la iglesia o que la custodia quedara en la puerta. En 1652 el Hospital de San Roque percibía seis pesos de cada representación hecha dentro del hospital y cuatro de las de afuera. Al parecer, el dueño del teatro o el hospital proveían viviendas gratis a las compañías mientras daban sus representaciones en la ciudad. En 1687 se hallaban "en la provincia de Tlaxcala y Ciudad de los Angeles" los comediantes Bernardo Pérez, Juan de Dios y Francisco Rascón.

En abril de 1598, el día 17, el Cabildo de Puebla de los Angeles acordó amenizar la fiesta del Santísimo Sacramento con una farsa, cuyos gastos se pagarían con los fondos propios de la ciudad. Ordenó asimismo que se comunicase con el escribano para que éste hiciese los convenios necesarios con el representante Juan Corral ${ }^{3}$ y su compañía, que se hallaban en la ciudad de México:

Este día se acordó que, por quanto la fiesta de Corpus Christi deste año está ya mui cercana, y es justo que esta ffiesta sea festexada, como es costumbre; por tanto, se acordó que a costa de los propios desta Ciudad se haga una ffarça y para este effeto se escriva a Marcos Rodrigues, escriuano deste Cabildo, que está en la Ciudad de México al presente, concierte con Juan Corral, rrepresentante para que con su quadrilla venga a esta Ciudad y hagan la dicha ffiesta, haciendo con ellos el concierto que convenga por el prescio que le paresciere quesso esta Civdad estará y pasará por él y si el prescio que pidieren ffuere excesiuo, 
escriva a esta Civdad, dando raçon dello, ansí del dicho prescio como de la ffarça que vuieren de hacer, para que sea qual convenga y ansí lo acordó; $y$ si no tuviere effecto el dicho concierto con los rrepresentantes de México, se acordó que se busque otra para que acuda a ello y tenga efecto la dicha fiesta. 4

E1 2 de mayo fué leida la respuesta del escribano, que informó que no había en la ciudad de México nadie que se encargase de ejecutar una farsa, y en consecuencia de esto se decidió dar comisión a dos regidores para que concertasen con el clérigo Rodrigo de Chárez la representación de una comedia:

Este día se acordó que por quanto por carta que Marcos Rodríguez, escrivano deste Cabildo, escrivió en rrespuesta de 10 que se le cometió sobre concertar vna comedia para el día de Corpus Criste deste año dise no ay en México persona que acuda a ello; por tanto, dan comisión e facultad a Juan Blas Ramírez e Pedro de Vribe, Regidores, para que en nombre desta Civalad se concietten con Rodrigo de Chaves, clérigo, para que se haga la dicha comedia por el prescio que les paresciere, que lo que hicieren e concertasen esta Civdad estará por ello y se pagará de los propios desta Civdad . . .5

Seis días más tarde, o sea el 8 del mes en cuestión, se ratificó el convenio hecho con Rodrigo de Chávez, obligánclose la ciudad a pagarle trescientos pesos por dar la farsa. Además, iban a lidiarse dieciséis toros el sábado, 16 del mes, como parte del programa de la fiesta:

Este día se acordó que por quanto, en virtud de vn acuerdo deste Cabildo, los Rregidores Juan Blas Ramírez y Pedro de Oribe concertaron con Rodrigo de Chatues vna farça, para el día de Corpus Criste deste año, en trezientos pesos de oro común, de que se le a dado libramientos al Mayordomo para que los pague de los propios; por tanto se acordó que apruevan e ratifican el dicho concierto, dando y pagando en virtud del libramiento a el dicho Mayordomo los dichos trezientos pesos. 6

Por espacio de nueve días, durante la fiesta de la Epifanía del año 1600 , estuvieron ocupados los jesuítas en festejar la terminación de su magnífico templo del Espíritu Santo y la colocación de las reliquias traidas de Roma por el padre Pedro de Morales. Celebraron ambos acontecimientos con las procesiones, juegos de cañas y de sortija y certámenes literarios de costumbre. El jueves fué con- 
sagrado a descubrir la nueva imagen de Nuestra Señora del Niño Dormido y, terminada la misa, dieron una pieza dramática, acompañada de danzas y música, que habían prevenido para ese propósito. El lunes en la tarde se repartieron los premios y tuvieron otra representación, una ingeniosa danza y recitaciones de unos colegiales de San Gerónimo:

Hoc anno tandem perducta est ad exitum Aedes sacta, cuitus pulchritudo cum recens ad oculos hominum petvenit, magnan habuit celebritatem et plaustm: est enim multorum opus annorum cum magnitudine nobile, tum atis varietate distinctum. Itaque prima dies... Feria tertia eius hebdomade theologice theses, presertim que ad celebritatem facere videbantut de templortm dedicatione et reverentia. Sanctorum imaginibus exhibenda in lectissima doctissimorum hominum corona disputate sunt. Fetia vero quinta in magna frequentia plebis musice concentu suavissimo tabula speciosissima Dei Genitticis Puetum Iestm ducentem sommos pie contemplantis, duobus puetis in speciem angelorum otnatis velamina aperientibus exposita, et confecto sacto datum drama splendidissimum, quod vel propter gravitatem carminis a poeta omnibus artis opibus exculti, vel proptet adiunctas singulari artificio choteas eruditis pariter et docttine expertibus vehementer placuit, $\mathbf{7}$

E1 jueues se eligió para la colocación de la imagen de Nutestra Señora del Niño Dormido, que se puso en el colateral de la Epístola: estando cubierto hasta aquel día en el qual antes de començat el coro a oficiar la missa, dos ángeles adereçados curiosa y costosamente, puestos a los dos cantos del retablo, fueron corriendo las cortinas, como lo pedía la música, y mostrando al pueblo la imagen que descubrían ganaron la atención de todos por la hermosura y belleza que mostraba la Reyna del Cielo en su pintura. Acabada la missa, se començó vna representación, que para este tiempo estaba apercebida, que por ser tan a propósito de la fiesta, acompañada de muy ordenadas danças y suauidad de música, fué de muy particular gusto a los oyentes... E1 lunes en la tarde se dieron los premios que fueron 15 pieças de plata costosa, y bien labradas, sin cantidad de christales y agnus guarnecidos. Acompañóse el dar de estos premios con vna curiosa y breue representación y vna ingeniosa dança y vnas declamaciones que hicieron dos colegiales de San Gerónimo, siendo vno de ellos también el juez...8

El día 2 de mayo de 1603, con el fin de asegurar la representación de una comedia para el Corpus, el Ayuntamiento nombró a los 
regidores Pedro de Uribe y Melchor de Cuéllar para que entrasen en tratos con los empresarios Riancho y Velázquez: ${ }^{9}$

En este día se acordó que, para el día de la fiesta de Corpus Christi deste año, se haga vna comedia en la catedral de la Ciudad a costa de los propios, y que, atento que ay dos compañias de comediantes, la vra de Riancho y la otra de Velázquez, para que se uea con qué de las compañias̀ sea más a propósito concertarse, se cometió a los Regidores Pedro de Vriue e Melchor de Cuellar, para que se puedan concertar con vno de los dichos autores por la cantidad de pesos de oro que les pareciese justo y hacer sobre ello asiento y que, en virtud desta acta, livran de los propios y la cantidad de oro consigne el Mayordomo. 10

En 16 del mismo mes informaron los regidores al Cabildo que habían contratado con Alonso Velázquez y Gonzalo de Riancho, obligándose la ciudad a pagar seiscientos cincuenta pesos de oro común por la representación de una comedia el día del Corpus. Acordóse que se hiciesen en la plaza pública cuatro tablados, uno para el $\mathrm{Ca}$ bildo, otro para los ciudadanos, el tercero para las damas y el cuarto para los comediantes:

Este día se platicó en el dicho Cabildo por los Rregidores Pedro de Vriue y Melchor de Cuellar cómo, en conformidad de la comisión que por el dicho Cabildo se les dió en dos días deste mes, se auían concertado con Alonso Belázquez y Gonzalo de Rriancho, autores de comedias, hiciesen una para el día del Corpus Cristi en la plasa pública de quatro que nombraron y señalaron. Y por ellas se les auía de dar seiscientos y cinquenta pesos de oro común de propios de Ciudad y se auía hecho escriptura sobrello por ante mí, el escriuano. E por la Ciudad bisto, aprouó el dicho concierto, auiendo sido enterado dél, y que se dé libramiento para quel Mayordomo de propios pague los dichos pesos del concierto.

Este día se acordó que para la dicha comedia se haga vn tablado en la dicha plaza en la parte que convenga y sea a costa de propios lo que en él se gastare, para que el dicho Cabildo ponga y tenga su asiento para el ber de la dicha comedia, el qual lo haga Pedro López Florín, Maestro de las Obras desta Ciudad. Y se encargó a Nicolás de Billanueva y Pedro Diez de Aguilar, Rregidores, el buscar gergas para los toldos que se an de hazer para que aya sombra. $Y$ asimismo se le encargó a Ántonio Rodríguez, Regidor, el buscar alfombra para los asientos y adorno del tablado del dicho Cabildo, para cuyo efecto se le notifique. 
Y el Alcayde de la cárcel Joan Gutiérrez tome a su cargo el haser poner las varas y los toldos que se an de hazer para cubrir el tablado y defensa del sol de aquel día; el qual tablado, digo tablados, han de ser quatro, el uno para el Cabildo y el otro para los ciudadanos, otro para las damas y otro para los farsantes, $y$ éstos se an de hacer conforme a el modelo que se diere a el dicho Pedro López o a la persona que los uiere de hazer. 11

Otros datos interesantes sobre comediantes que deseaban actuar en Puebla en 1603 revelan que el Virrey concedió licencia el día 19 de junio, a los empresarios Antonio Rodríguez y Juan Corral, para trabajar alli sin competencia alguna de otras compañías durante los dos primeros meses siguientes a esta orden. Asimismo se estipuló que en adelante debían obtenerse licencias del Virrey, "sin que las dadas para ésta de México señaladamente valgan ni se entiendan para la dicha Ciudad de los Angeles". ${ }^{12}$

En 1613 el carpintero Juan Gómez Melgarejo, quien había improvisado un teatro en su casa, se vió en apuros con el Ayuntamiento, el cual amenazó derribar la casa y multarle con doscientos pesos si no cesaban las funciones dramáticas:

En la Ciudad de los Angeles, a primero día del mes de junio de mill y seiscientos y treze años, el Regidor Nicolás de Villanueva Guzmán. Teniente de Alcalde Mayor en ella, mandó que, por justas causas que convienen, se notifique a Juan Gómez Melgarejo, vesino de esta dicha Ciudad, no consienta que en su cassa de aquí adelante, y asta que otra cosa se prouea y mande, se hagan comedias ni repressentaciones en manera alguna, so pena de doscientos pesos de oro común para la cámara de Su Magestad en que desde luego le da por condenado, lo contratio hasiendo, y demás de ello se le derribara el teatro que tiene hecho y assí lo proueyó, mandó y firmó. Nycolás de Uillanueva... 13

Las tradicionales fiestas del Corpus continuaron, como se colige del acuerdo tomado por el Ayuntamiento el día 22 de mayo de 1615. Se ejecutó la comedia, según las actas del 29, en un tablado levantado en la plaza pública:

Este día se cometió al dicho Señor Alcalde Mayor y a Juan de Carmona Tamarís, Depositario General y Procurador Mayor desta Ciudad, traten con los farsantes, que de presente están en 
esta Ciudad, se haga vna comedia el dia de Corpus Christi deste año, en forma de la misma fiesta a la puerta de la yglesia cathedral o en la parte que más conuiniere, y la concierten por el precio que a él paresciere, el qual se pague de los propios desta Ciudad $y$, para haser el dicho concierto $y$ otorgar escriptura y dar libramiento de los pesos de oro en que assi lo concertaren, se les dió poder y comissión en forma qual de derecho se rrequiere $y$ a qualquiera de ellos yn solidum. 14

Este día se acordó que an de empregar la hechura de los tablados que se an de hazer en la plaza pública para la rrepresentación el día de la fiesta del Corpus Christi deste año de la forma y traça que otros años se an hecho, y se rresciben las posturas y haga el tremate ante el Señor Alcalde Mayor y Juan de Carmona Tamarís, Depositario General desta Ciudad, a quien está cometido el concierto de la farsa y, para ello y librar los pesos de oro en que fuere becho el rremate, se le dió comissión en forma qual de derecho se rrequiere, los quales dichos pesos pague el Mayordomo desta Ciudad a costa de propios della $y$, en birtud del libramiento que dieren los dichos comissarios y carta de pago de la persona en quien se vuiere hecho el rremate, se le passen en cuenta en la que diere de los dichos propios de Ciudad. 15

E1 6 de mayo de 1616 la ciudad tomó la resolución, en vista de la falta de comediantes, de celebrar la fiesta del Corpus Christi con danzas de indios. Arreglóse también que fuese hecha una tarasca ${ }^{10}$ que anduviese en las procesiones por las calles. Las actas del día 17 del mismo mes dan noticias sobre el costo y manera de pago de la tarasca :

Este día la dicha Ciudad dixo que, por quanto el día de la fiesta del Corpus Christi está muy cercano $y$, por no auer farsantes de rrepresentación, no será possible hazerse comeđia aquel día, como es costumbre, $y$, para que aya algunas danças $y$ bayles que rregosijen la fiesta, se acordó que el Señor Alcalde Mayor hable al gouernador de los yndios desta Ciudad, para que cada barrio dellos que ay en ella salgan tres danças, differentes vnas de otras, que regozijen la dicha fiesta como dicho es aquel día.

Este día se acordó que el dicho Señor don Tristán de Luna y Arellano, Alcalde Mayor, y Juan de Carmona Tamarís, Depositatio General desta Ciudad, trasen con Bartolomé de Moya, carpintero, vezino della, haga vna tarasca para que ande por las calles el día de Corpus Christi deste año y los venideros, a ymitación de cómo se hazen en otras ciudades de España, y sobrello hagan qualesquier conciertos por el tiempo y precio que 
bien visto les fuere a costa de los propios de la dicha Ciudad, obligándolos a la paga de los pesos de oro que concertaren y por libramiento qual conuenga para que los pague el Mayordomo desta Ciudad, otorgando escriptura en forma con las fuerças y promezas necessarias para su validación, que para ello se le dió poder y comissión en forma qual de derecho se rrequiere con general administración y rreleuación. 17

Este día la dicha Ciudad, auiendo visto la postura que tiene hecha Bartolomé de Moya, carpintero, en la hechura de la tarasca que se a ordenado hazer para la fiesta del Corpus Christi $y$, conferido en rrazón dello, se acordó que la dicha tarasca se paga en la forma que tiene offrescida el susodicho. por quatro años y que por este primero año se le paguen cien pesos de oro común $y$ por los tres adelante a ochenta pesos cada año $y$, aceptando éste el dicho Bartolomé de Moya, se le dé libramiento por los cien pesos deste primeto año, obligándose de cumplir lo que tiene offrescido por su postura, so pena de boluer los cien pesos con el costo. 18

Dos años más tarde, el $1^{\circ}$ de junio de 1618, el regidor don Felipe Ramírez de Arellano presentó al Cabildo una petición en que, después de llamar la atención al hecho de poseer un solar en cuyo edificio había gastado mucho dinero "para hazer vn patio y teatro de comedias", rogó que se le concediese licencia para explotar el único teatro durante veinte años. Al considerar dicha solicitud, el Ayuntamiento tomó nota de que en el corral, usado entonces. para las funciones dramáticas, se iban construyendo viviendas, y de que el sitio del señor Ramírez de Arellano era "acomodado y anchuroso" y en la quadra inmediata a la plasa pública, cerca de la Audiencia Ordinaria, a bista de la Justicia". Estas razones decidieron a los regidores a dar la licencia pedida por su colega. El día 18 del mismo mes el Marqués de Guadalcázar, Virrey de la Nueva España, aprobó y confirmó la licencia otorgada por el Cabildo de Puebla:

Este día el dicho Regidor Don Phelipe Ramírez de Arellano presentó en el dicho Cabildo vna petición firmada de su nombre $y$, antes de leerla, mandó la dicha Ciudad se salga del dicho Cabildo el dicho Regidor y, luego se salió dél, yo el escriuano doy fee y, estando fuera dél, se leyó la dicha petición por mí el dicho escriuano, cuyo tenor es como se sigue: "Don Phelipe Ramírez de Arellano, Regidor de esta Ciudad, digo que, como a Vuestra Señotía consta, yo tengo un solar, junto a las posessiones del mayorazgo de mi padre, en cuyo edifficio tengo gastado mucha cantidad de pessos para hazer vn patio $y$ teatro de comedias para 
el entretenimiento y regozijo de esta Ciudad. A Vuestra Señoría pido y suplico, pues le consta que es parte conueniente y acomodada para el dicho efecto, me dé licencia por tiempo de veinte años para hazer el dicho teatro y que durante el dicho tiempo otra persona vecina en esta Ciudad no pueda hazer otro teatro, que de ansí mandar recebiré merced. Don Phelipe Ramírez de Arellano." Por la dicha Ciudad vista, considerando que el corral, en que hasta el día de oy se hazían las comedias, se ban edificando en él casas de biuienda y que la parte que refiere la dicha petición es lugar acomodado y anchuroso y en la quadra inmediata a la plasa pública, cerca de la Audiencia Ordinaria, a bista de la Justicia y, que, por estarlo, podrá acudir con presteza a euitar los ruydos $y$ alborotos que podrian subceder. Dixo que daua $y$ dió licencia al dicho Regidor Don Phelipe Ramírez de Arellano para que en el dicho sitio pueda hazer casa $y$ teatro de comedias donde se representen, por espacio de veinte años primeros siguientes, sin que otra persona alguna pueda hazer teatro en otra parte durante el dicho tiempo, so pena que se le demolerá la obra que hiziere, por quanto la parte y lugar que el dicho Regidor of rece tiene las comodidades referidas $y$, esto hecho $y$ acordado, bolvió a entrar en el dicho Cabildo el dicho Regidor Don Phelipe Ramírez de Arellano y, auiendo entendido lo susodicho, 1o aceptó y pidió dello se le dé testimonio para en guarda de su, dicho y la dicha Ciudad se lo mandó dar. ${ }^{19}$

En la Ciudad de México, a diez y ocho días del mes de junio de mill y seiscientos y diez $[y]$ ocho años, Don Diego Fernández de Córdoua, Marqués de Guadalcáçar, Virrey y Lugarteniente del Rey, Nuestro Señor, Gouernador y Capitán General desta Nueua Spaña y Presidente de la Audiencia y Chancilleria Reales quen (sic) ella residen. Auiendo visto lo pedido por Don Phelipe Ramírez de Arellano, vezino y Regidor de la Ciudad de los Angeles, cerca de que Su Excelencia mande aprouar y confirmar la licencia que la Justicia, Cabildo y Regimiento de la dicha Ciudad le dió para que en un solar suyo que tiene hedificado junto a la plaça de la dicha Ciudad pueda tener teatro donde se reciten comedias por tiempo de veinte años, según se contiene en el término de la fecha de en contra. Dixo que, sin perjuicio de tercero, aprobaua y confirmaua y aprouó $y$ confirmó la dicha licencia y mandaua y mandó se guarde y cumpla según y como en ella se contiene y assí lo proneyó y firmó. El Marquéz de Guadalcáçar. Ante mí, Pedro de la Torre. Corresponde con el original que se boluió al Regidor Don Phelipe Ramírez de Arellano y lo firmé. Nicolás Fernández de la Fuente, escrivano de Cabildo, 20 
Gonzalo de Riancho, contratado para representar una comedia en la capital durante el Corpus del mismo año (1618), se fué a Puebla a trabajar sin conseguir previo permiso del Ayuntamiento de México. Para hacerle regresar con su compañia sin dilación, el Cabildo acordó suplicar al Virrey que así lo mandase a Riancho, en una carta dirigida al Alcalde Mayor de Puebla:

Y por cuanto, para el día próximo de la octava desta festividad, 1a Ciudad tiene ordenado que Gonzalo de Riancho, autor de comedias, haga una de que hoy no ha dado muestra, y está en la Puebla, donde dicen que representa el domingo infra octava de esta fiesta y, saliendo después de este día de la Puebla, respecto de la cantidad de leguas hay y del embarazo con que estas compañías fuesen (sic) caminar, puede ser que siga el tiempo que ni dé muestra a la Ciudad ni al Tribunal del Santo Oficio de la Inquisición, como hasta aquí se ha dado, y que venga la Ciudad a hallarse sin fiesta que hace aquel día, que sobre el inconveniente pasado vendrá a ser cualquier tropiezo que haya en esto de gran momento y consideración, ha suplicado a la Ciudad se junte hoy en su Cabildo para que provea lo que en esto más convenga, y así lo suplica, con que él quedará libre de la obligación que tiene a mirar por esto, y la Ciudad terná a su cuenta el asierto u el desacierto que en esto hubiere...

$Y$ en cuanto a la otra parte de la propusición que contiene, que se provea dé remedio para que las muestras sean a tiempo que se puedan exraminar y calificar por las personas a quien toca, se ordene que el dicho Señor Procurador Mayor suplique a Su Excelencia mande dar una carta para el Alcalde Mayor de la Puebla, donde está Gonzalo de Riancho, para que luego al punto, sin dilación alguna, le haga venir a esta Ciudad de suerte que el lunes por la mañana él y su compañía estén en esta Ciudad, de suerte que a la tarde dé la muestra a la Ciudad y para esta diligencia se despache un correo en toda diligencia a las treinta yente y biniente, y el Mayordomo pague por cuenta del dicho Gonzalo de Riancho la costa que tuviere esto de lo que se le hubiere librado $y$ hubiere de haber, por cuanto se fué desta Ciudad sin licencia della ni del Señor Corregidor, y el dicho correo con la dicha diligencia traiga certificación de la hora que entrega a[1] Alcalde Mayor el despacho y se notifique esto luego al Señor Procutador Mayor. 21

Las noticias pertinentes a la fiesta del Corpus del año 1622 muestran que el Cabildo nombró a tres regidores, a quienes encargó de hacer los convenios necesarios con los autores y comediantes, a la 
vez que se aludió al hecho de que solian representarse las comedias a la puerta de la catedral, delante del Santísimo Sacramento:

En la Muy Noble y Muy Leal Ciudad de los Angeles de la Nueua España, a quatro días del mes de mayo de mill y seiscientos $y$ beinte $y$ dos años... la dicha Ciudad dixo que por quanto la fiesta del Corpus Christi está muy cercana en cuya celebridad se acostumbra hazer comedias a la puerta de la yglesia cathedral delante del Santíssimo Sacramento y para que el pressente año de la fecha, en prosecución de la costumbre, se haga comedia se acordó que los Señores Regidores Pedro de Vriue, Juan Antonio de Aguilar y Francisco Sánchez de Gueuara la concierten con los autores y comediantes y por el precio que les pareciete a costa de propios de Cíudad y lo mismo los tablados para la rrepresentación y para el asiento de Cabildo, librando los pesos de oro del dicho concierto en el Mayordomo de los dichos propios para que los pague, que para todo ello, y lo dello dependiente, se le dió poder y comissión en forma qual de derecho se rrequiere y para otorgar escripturas en rrazón de lo susodicho, a cuya promesa y paga se obligan los dichos propios...22

Transcurría el año de 1626 y la ciudad, enterada en la sesión del 29 de mayo de lo cortos que eran sus fondos económicos y convencida de que se podría remediar la situción con la renta de un corral, mandó al Procurador Mayor escribir al Virrey, suplicándole licencia para efectuar su proyecto:

Este día la dicha Ciudad dixo que por quanto su bezindad y poblazión ba en muy grande crecimiento, y cada dia se espera yrá en mayor augmento, y juntamente sus propios son tan cortos que no puede sustentar sus obras $y$ otros gastos forçosos y ynescusables y le podría ser de muy grande ayuda hazer en ella vn corral de comedias que pudiese arrendar y la renta se conuirtiesse en los dichos propios con que también se escusaran otros inconvenientes muy grandes que se an considerado. Por lo que se acordó que el Regidor Juan de Narváez, Procurador Mayor desta Ciudad, escriua carta al Excelentísimo Señor Birrey desta Nueua España, suplicándole en nombre della le conceda licencia y facultad para ello en la forma que a entendido en este Cabildo, para lo qual haga assí mismo memorial y lo remita $y$ ordene a Juan Antonio de la Reguera, Solicitador en la Real Audiencia de México, solicite la causa. 23 
Unos tres meses después, o sea el $1^{\circ}$ de septiembre, fué recibida la respuesta del Virrey, quien concedió para fundar un corral, ordenando al mismo tiempo que parte de las ganancias se entregasen al hospital (las actas del 23 de octubre revelan que el Virrey ordenó dar al Hospital de los Indios seis pesos de limosna de las entradas. de cada representación):

Este día se vió en el dicho Cabildo un mandamiento del Excelentísimo Señor Marquéz de Cerralbo, Birrey desta Nueva España, dirigido al Señor Alcalde Mayor para que informe a $\mathrm{Su}$ Excelencia, en rrazón de la licencia que de parte desta Ciudad se le pide, para hazer vn corral de comedias y se acordó que el dicho mandamiento se entregue al Señor Regidor Joan de Carmona Tamarís, Depositario General, para que lo pressente ante el dicho Señor Alcalde Mayor, pidiendo su cumplimiento, que para ello $y$ hazer los autos y diligencias que conuengan hasta que tenga cumplido efecto el alcançar la dicha licencia, se le dé poder qual de derecho se requiere con general administración y relación en forma. E1 tenor del dicho mandamiento es como se sigue: "Don Rodrigo Pacheco Ossorio, Marqués de Cerralbo, del Consejo de Guerra, Birrey, Lugartheniente del Rey, Nuestro Señor, Gouernador y Capitán General desta Nueua España y Presidente de la Audiencia y Chancillería Rreal que en ella reside, por quanto Joan Naruáez, Regidor de la Ciudad de los Angeles y Procurador Mayor della en su nombre me a hecho relación que, rrespecto de las necessidades que la dicha Ciudad padesce por la cortedad de sus propios y rrentas y de los censos que paga y que trae deudas que nueuamente a contraydo para seruir a Su Magestad, como lo a hecho en los préstamos y donativos que se an offrecido estos años, a pensado le sería de algún socorro hazer vn corral para la representación de las comedias que hazen en la dicha Ciudad las compañías que ban de ésta, con la misma pinsión que da la persona que le tiene en la dicha Ciudad al ospital de los conualecientes della. $Y$, atento queste socorro es más justo que lo tenga la dicha Ciudad que no otro ninguno particular, me pidió le concediese esta gracia, merced y licencia para que pueda hazer y fundar el dicho corral en la dicha forma y con la dicha pinsión y por mí bisto, por el pressente mando a uos el Alcalde Mayor de la dicha Ciudad de los Angeles o vuestro Lugarteniente me informéis sobre lo rreferido y del corral que ay en ella para el dicho efecto. Y notificando el dicho pedimento al dueño dél y a la parte del dicho ospital, para que rresponda con buestro pareser, me lo remitiréis. Dado en México, a veinte y siete días del mes de agosto de mill y seiscientos y beinte y seis años. El Marqués, por mandado de Su Excelencia. Joạn Gómez Tonel de Sotomayor." 24 
E luego, el dicho Regidor Juan de Naruáez hizo demostración y exhiuió en el dicho Cabildo una merced y licencia dada por el Excelentíssimo Señor Marqués de Cerralbo, Birrey desta Nueua España, para que esta Ciudad pueda fundar vn corral de comedias para propios della, dando de limosna de cada comedia que se rrepresentare seis pesos a el Ospital de los Yndios desta Ciudad, prefiriendo a las demás personas que tuuieren otras licencias. Su fecha en México, a diez y siete deste mes de octubre de mill y seiscientos y beinte y seis años. Refrendada del Secretario Juan Gómez Tonel de Sotomayor, ${ }^{25}$

En el acta del mes de octubre del mismo año (1626) se encuentran unos datos interesantes relativos a

LO GASTADO EN LO DEL CORRAL DE COMEDIAS:

Quatro pesos y dos tomines del mandamiento compulsorio que ymbié para las diligencias en el corral de comedias, y citación de los ynteresados de todo del pago del Secretario y officiales, triplicados los dichos.

4 Ps. 2 To.

Vn peso a Laynez. Official Mayor de la pressentación deste negocio.

1 Ps.

Yten más quatro tomines al dicho Laynez de la remissión al Doctor Barrientos.

Yten quinze pesos que di de accesoria a el dicho Doctor Diego de Barrientos deste negocio y dos pesos al Licenciado Escobar, su escriuiente.

Yten di a el Secretario Juan Gómez Tonel destos dos despachos de alhóndiga y comedias ochenta pesos por la gracia y solicitud.

Yten pagué a Antonio Laynez, su Oficial Mayor, de ambos despachos $y$ alhóndiga y comedias diez y seis pesos a é1 solo. 16 Ps.

Yten a el escriuiente que escrivió los despachos y trasladó las ordenanças y executoria de México ocho pesos, y de assentar en el libro general ambos negocios tres pesos, que todo monta onze pesos. ${ }^{26}$

$11 \mathrm{Ps}$.

129 Ps. 6 To.


En el mes de abril de 1630, el empresario Juan Antonio de Sigüenza trabajaba con su compañía en Puebla. Reclamó al Cabildo de la ciudad de México trescientos pesos pagados con anticipación por volver a ésa a representar comedias para la fiesta del Santísimo Sacramento :

$Y$ así mismo servido la requisitoria, que el Señor Corregidor despachó, que mandó cumplir el Alcalde Mayor de la Ciudad de los Angeles en razón de que los farsantes viniesen a hacer las comedias para esta fiesta, y la carta que respondió dicho Alcalde Mayor, y otra de Juan Antonio de Zigüenza, autor de comedias, en que, insinuando imposibilidad de su venida, of rece venir socorriéndole con trescientos pesos, aunque sea a cuenta de lo que hubiere de baler de la fiesta. 27

Dos años más tarde, en el verano de 1632, se hallaban dos compañías de actores en Puebla, una de Ana María de los Angeles y la otra de Hernando Ramos. Desde hacía algún tiempo aquélla trabajaba allí con sus comediantes y, por lo consiguiente, objetó vigorosamente la presencia del recién llegado Ramos, alegando ella que no había tratado de ir a la capital y que, por falta de salud y comedias nuevas, le sería muy inconveniente hacerlo. Al parecer, Hernando Ramos obtuvo la licencia, habiéndose valido de falsos testimonios a la vez que prometió volver a la ciudad de México en caso de no querer salir de Puebla la compañía de Ana María de los Angeles. Francisco de Mier, a cuyo cargo estaba la compañía de Ramos, contradijo a la dicha señora, dando a entender que ella tenía muchas comedias nuevas (hacía ocho meses que no había trabajado en la capital) y que se negó a salir de Puebla sólo cuando no se le entregaron los quinientos pesos que reclamó por marcharse. A pesar de todo, Hernando Ramos se quedó en Puebla y todavía trabajaba allí a fines del año:

Don Rodrigo Pacheco Osorio, etc., por cuanto Gonzalo Jaramillo, en nombre de Ana María de los Angeles, autora de comedias, me ha hecho relación que por mí se concedió licencia a Hernando Ramos, asimismo autor de comedias, para que fuese a representar a la Ciudad de los Angeles, donde está la compañía de la dicha Ana María, por haberme informado que la susodicha quetía volverse a ésta de México, siendo así que ni ha tratado de ello ni tiene comodidad para poderlo hacer, por estar con falta de salud y no tener comedias nuevas que representar en 
ella, y que el Alcalde Mayor de la dicha Ciudad de los Ángeles, por favorecet al dicho Hernando Ramos, mandó que dentro de seis días saliese de ella la dicha Ana María, sin embargo de la apelación que interpuso para ante mí, de lo cual se le sigue muchos daños y gastos irreparables, pidiéndome mande que la compañía del dicho Hernando Ramos sea la que haya de volver a esta Ciudad, pues con siniestra relación obtuvo la dicha licencia y tiene obligación de asistir en ella por haber representado la fiesta de Corpus Cristi, y que la compañía de la dicha Ana María se presente en la dicha Ciudad de los Angeles, sin embargo de lo mandado por el dicho Alcalde Mayor; y por mí visto y que a un memorial que se me presentó por parte del Hospital Real de los Indios de esta Ciudad, en razón de que por haber salido de ella el dicho Hernando Ramos, sin que hubiere venido la compañía de la dicha Ana María, cesaba la limosna que tenía el dicho hospital en el corral donde se representan las comedias, proveí un decreto a diecisiete de este presente mes de que, cuando me pidió licencia para irse el dicho Hernando Ramos, se obligó verbalmente en mi presencia a que, si la dicha compañía de Ana María no estuviese para partirse a esta Cindad, que lo hiciese luego, él se volvería a ella, con lo cual y haber traído ante mí un carretero y un arriero de la Puebla, que dijo haberle dicho en ella los dueños de la dicha compañía de Ana María que se querían venir luego que llegase el dicho Hernando Ramos; le di la licencia con la dicha condición, y, atento a esto, se despachase mandamiento a la parte del dicho hospital para que el A1calde Mayor de la Ciudad de los Angeles hiciese que se cumpliese en la forma dicha, que, no viniendo la compañía de la dicha Ana María, viniese la de Hernando Ramos: por el presente mando al Mariscal de Castilla Don Tristán de Luna y Arellano, Alcalde Mayor de la dicha Ciudad y mi Teniente de Capitán General, guarde el dicho decreto, y en su cumplimiento, compela a la compañía del dicho Hernando Ramos a que, dondequiera que estuviere, se venga a esta Ciudad, sin dejarla representar en ninguna parte, enviando persona a su costa que la traiga, sacando cincuenta pesos de multa al arriero que la llevó, por haberme hecho siniestra relación, los cuales aplico al dicho Hospital Real, dejando representar en la dicha Ciudad de los Angeles a la compañía de la dicha Ana María. Fecho en México, a veintiocho de julio de mil y seiscientos y treinta y dos años. El Marqués de Cerralvo. Por mandado de Su Excelencia, Luis de Tovar Godínez, 28

Después de lo cual, Francisco de Mier, a cuyo cargo está la compañía del dicho Hernando Ramos, me ha hecho relación que Inés de Espinosa, mujer del susodicho, está preñada y cercana al parto, tanto, que si se pusiese en camino para venir a esta Ciudad, correría muy grande riesgo su vida, como constaba por la 
información, declaraciones de médicos y comadres de parir, de que hacía presentación, por lo cual está imposibilitada de poder cumplir lo que le está mandado, demás de que la dicha Ana María, autora de la otra compañía, tiene muchas comedias nuevas que poder representar en esta Ciudad, donde venía para el dicho efecto, y encontrándola (la) del dicho Hernando Ramos, les pidió quinientos pesos para venirse, $y$, como no se los dieron, no quiso pasar adelante, pidiéndome que, atento al impedimento referido, mande que el dicho mandamiento inserto se entienda con la compañía de la dicha Ana María de los Angeles, por estar más dispuesta a venir a esta dicha Ciudad por las comedias nuevas que puede representar, haber ocho meses que falta de ella, que estando la dicha Inés de Espinosa libre de dicho embarazo, está presto de cumplir lo que está mandado; y por mí visto y lo pedido cerca de esto por Vicente López Montaño, Administrador del Hospital Real de los Indios de esta dicha Ciudad, por lo que toca a los pobres de él, por el presente mando se guarde y cumpla y ejecute el dicho mandamiento inserto, en todo $y$ por todo, según y como en ella se contiene y declara, sin que contra su tenor y forma se vaya ni pase en manera alguna. Fecho en México, a veinte de agosto de mil y seiscientos y treinta y dos años. El Marqués. Por mandado de Su Excelencia, Luis de Tovar Godinez. 29

Don Rodrigo Pacheco Osorio, etc., por cuanto Ana María de los Angeles, autora de comedias, me ha hecho relación (que) tiene su compañía en esta Ciudad, donde vino de la de los Angeles en tiempo de aguas con mucha incomodidad, y que no la habia para que la gente pudiese ir a la comedia por la inundación que padece y no haber calzadillas, y que habiendo llegado a su noticia había una festividad a dieciocho de enero del año que viene de seiscientos y treinta y tres que corre, por cuenta de la Ciudad, dío petición en el Cabildo de ella y se proveyó en su favor y dió la dicha fiesta en consideración de lo referido, lo cual está aprobado por mí, y que, teniendo noticia de ello, Hernando Ramos, autor de otra compañía de comedias que al presente está en la Ciudad de los Angeles, ha dado petición en el dicho Cabildo, diciendo hará graciosamente la dicha fiesta, sólo a fin de lograr sus atrevimientos $y$, después de haber sído inobedientes a mis mandatos y frustrar la comodidad de la dicha Ana María, pidiéndome mandase despachar el recaudo necesario para que no pueda entrar en esta Ciudad ninguna compañia de comedias hasta que haya pasado la dicha fiesta; y por mí visto, por el presente mando a vos, cualquier escribano público o real, notifiquëis al dicho Hernando Ramos no traiga su compañía a esta Ciudad de México, sin licencia particular mía, en consideración de lo que pasó cuando se fué de ella, dando testimonio a la 
parte de la dicha Ana María, para en guarda de su derecho. Fecho en México, a seis de diciembre de mil y seiscientos y treinta y dos años. El Marqués. Por mandado de Su Excelencia, Luis de Tovar de Godínez. ${ }^{30}$

En la junta celebrada el 13 de mayo de 1644 fué propuesto que se invitase al Ilustrísimo Señor don Juan de Palafox y Mendoza (entró a ocupar la silla episcopal en 1640) y su Cabildo Eclesiástico a asistir a la representación de las dos comedias religiosas que iban a representarse el día del Corpus y la octava a la puerta de la catedral enfrente de la custodia del Santísimo Sacramento, como de costumbre. Seis días después, o sea el 19 del mismo mes, se supo que el jefe espiritual no sólo se negó a aceptar el convite para sí y su Cabildo, por parecerle las representaciones dramáticas una distracción repugnante, sino que prohibió que se pusiesen tablados y asientos en la parte señalada por sagrado de la iglesia y que la custodia quedase en la puerta. Asimismo expresó el deseo de que los tablados no se colocasen tan cerca de la iglesia, siendo la plaza tan extensa. A1 día siguiente, el 20 de mayo, se reunieron los regidores para considerar la respuesta del señor Obispo y tomar una decisión con respecto a los arreglos para la fiesta. La mayoría votó por guardar la costumbre y llevar a cabo lo proyectado, en la primera junta que trató de este asunto:

En la Muy Noble y Muy Leal Ciudad de los Angeles, viernes, treze de mayo de mill y seiscientos y cuarenta $y$ cuatro años... Este día el Alcalde Mayor propuso y dixo cómo esta Ciudad avía dispuesto la zelebridad del día del Corpus y su octaua benidera deste presente año, como era costumbre, procurando emplear todas sus fuerzas en auentajar sus regosijos $y$ lucimiento en onrra de $\tan$ gran fiesta, como se haze en toda la monarquía católica y Su Magestad lo tiene tan encargado, y porque entre otras prevenziones que para ello se an hecho son dos comedias a lo diuino que se an de representar el dicho dia y octaua a la puerta de la yglesia catted[r]al delante de la custodia del Santísimo Sacramento, como se a costumbrado y acostumbra $y$ como se a hecho siempre de tiempo ynmemorial, $y$, para que esta fiesta tenga todo complemento, le parese se enuíe recaudo al Excelentísimo Señor Don Juan de Palafox y Mendoça, Obispo deste obispado y a su benerable Cauildo, suplicándoles se siruan de onrrar a esta Ciudad, asistiendo a dicha fiesta, como lo an hecho siempre que se a hecho. $Y$ por la Ciudad visto, dixo se haga como el Señor General Don Gonzalo de Seruantes lo a 
propuesto, para lo qual nomvró por comisario, para que baia con esta legasía al Excelentísimo Señor Obispo y a su Deán y Cauildo, suplicándoles asistan a la representación de dichas dos comedias que son a lo dinino, muy debotas y ejemplares, al Señor Alférez Mayor Don Gerónimo Pérez de Zalazar...

En la Muy Noble y Miny Leal Ciudad de los Angeles, juebes diez y nuebe de mayo de mill y seiscientos y quarenta $y$ cuatro años... Este día el Señor Alférez Mayor Don Gerónimo Pérez de Zalazar dixo cómo, en conformidad de el acuerdo del Cauildo de trece de este presente mes y año, fué a ciar vn recaudo al Excelentisiño Señor Don Juan de Palafox, Obispo de este obispado, suplicando a Su Excelencia onrrase a esta Ciudad con asistir a la fiesta de la representación del día del Corpus; a que respondió que su dictamen era de no oyr comedias ni que el Cauildo Eclesiástico ni otro ninguno de sus clérigos las oyesen, por parecerle entretenimiento de que no resulta prouecho a las almas. Y que auiéndolo assí dado a entender a sus feligreses no era justo aplaudir con asistir lo que repugnaua, ni tampoco consentir que en la parte que estaua señalado por sagrado de la yglesia se hiziesen tablados ni pusiesen otros ningunos asientos, ni que la custodia auía de quedar en la puerta y que en lo demás que no le tocaua la Ciudad hiziese lo que por bien tubiese, que sólo sentía que, siendo la plasa tan grande, se pusiesen los tablados tan zerca de la yglesia don se an de zelebrar los offisios diuinos. $Y$ con esto se acauó el dicho Canildo...

Este día [viernes, 20 de mayo de 1644] aviendo juntado la dicha Ciudad y buelto a ver la respuesta que el Señor Alférez Mayor dió en el Cauildo de diez y nueve del presente del recaudo que de parte desta Ciudad llevó al Señor Obispo y conferido sobre ello, atento a no estar confformes, dió cada Capitular su boto y parecer en la manera siguiente:

El Alférez Mayor dixo que, atendiendo a la respuesta y ynsignuación del Señor Obispo, su parecer es se quiten los tablados enpesados frente de la yglesia mayor y se hagan frontero de las cajas reales donde se respresenten para regosijo del pueblo y zelebridad de la fiesta las dos comedias por estar ya pagadas y éstas sean, la vna vn día después de Corpus por la mañana y la otra el penúltimo de la octaua, por no embaraçar los días de procesión. y éste es su boto y parezer.

El Señor Alguacil Mayor dixo que, auiendo visto y entendido en la conferencia que todos estos Señores Regidores an tenido, en razón de la respuesta que traxo el Señor Alférez Mayor del Excelentísimo Señor Don Juan de Palafox y Mendoça deste obispado del Consejo de Su Magestad y su Visitador, en rasón de si se aurá de representar las dos comedias el 
dia del Corpus y su octaua en su solemnidad por obrar ynconvenientes, su boto y pareser es que se consulte a el Excelentisimo Señor Conde de Saluatierra, Virey de esta Nueba España, y yo el presente escrivano saque testimonio de los acuerdos hasta el de oy, y con carta se remita a $\mathrm{Su}$ Excelencia y en el yntervalo, si no se siruiese de responder, se haga la fiesta en la forma $y$ manera que está ordenado, eseto las dos comedias en la parte donde está enpesado a poner el tablado ni en la que el Señor Alférez Mayor dize y que se despache con propio a quien se den veinte pesos para que pueda yr y bolber, y éste es su boto $y$ parecer.

El Señor Regidor Don Juan Gómez Vasconzelos dixo que es del boto y parecer del Señor Alférez Mayor.

E1 Señor Regidor Alonso Días de Hertera dixo que, atento de estar el gasto hecho y por la autoridad de la Ciudad y los tablados que están hechos en la puerta de la yglesia se pasen frontero de las casas de Cauildo, donde la Ciudad asista en su balcón y las comedias se hagan los días acostumbrados, y éste es su pareser.

El Señor Don Francisco de Aguilar dixo que, atento a que esta Ciudad a continuado con costumbre ynmemorial demás de cient años zelebrar la fiesta del Corpus con las demostraciones y alegrías mayores y que las que an llenado la fiesta, siempre a sido representar dos comedias a la puerta de la yglesia catedral desta Ciudad, escoxiendo las más adequadas y onestas para tal caso, donde an asistido todos los Señores Obispos que [ha] auido en esta Ciudad y Cauildo Eclesiástico y que en esta costumbre se an continuado hacer siempre en la parte y lugar donde están enpesados los tablados y la representación y bestuario, enffrente de la puerta mayor de la yglesia, donde siempre se a puesto la custodia con el Santísimo Sacramento, a cuya onrra se an hecho $y$ hacen las dichas comedias y fiesta $y$, en esta confformidad, se acordó por esta Ciudad que, como patrón que le cupo, por turno dispusiese la dicha fiesta en conpañía del Señor Regidor Grauiel Escudero de Rocas y concertasen las comedias a lo diuino y de los propios de la Ciudad se pagasen con los demás gastos en cuya conformidad y de la costumbre y posición en que a estado la Ciudad y obligasión que tiene por las órdenes y mandatos de Su Magestad, para que a esta fiesta se hagan todos los regosijos posibles, conzertó las dichas dos comedias y tablados y pagó de los propios de la dicha Ciudad al autor de ellas $y$ al carpintero para los tablados y tiene dispuestos otros regosijos y para que lo tubiese la dicha fiesta, pues es obligación de las cauessas y Cauildos el continuar, se acordó por esta Ciudad se le diése parte a el Señor Don Joan de Palafox y Mendoça, Obispo meritísimo de esta Ciudad, y 
a su Cauildo de que se tenían dispuestas dos comedias muy ejemplares a lo diuino para que las asistiese, si fuese seruido, y a esta resolusión se le cometió darla a el Señor Alférez Mayor, que aviendo visto su respuesta y las palabras que el Señor Obispo dió por ella, es su boto y parezer que no prosi[g]ue el que se dejen de hazer que en la parte y lugar donde siempre, como tiene referido se a continuado, se continúe en la forma que está dispuesta los días de Corpus y su octaua, pues de hacerlas en onrra de tan gran fiesta no se puede seguir ningún ynconbeniente y se cumpla con la obligación que la dicha Ciudad por lo que Su Magestad tiene mandado, y éste es su boto y pareser.

El Señor Regidor Juan Ortís de Castro dixo que se conforma con lo que la Ciudad acordó en el primer Cauildo en que se trató de esta materia.

El Señor Regidor Juan Martínez de Águayo dixo que dize lo mismo que el Señor Regidor Juan Ortís de Castro.

El Señot don Juan de Carmona dixo que se conforma con el pareser que dió el Señor Regidor Alonso Días de Herrera.

El Señor Regidor Don Grauiel (sic) de Anzúrez dixo que se conforma con el boto del Señor Regidor Ortís de Castro.

El Señor Regidor Don Juan de Llanos dixo que su boto es que se guarde la costumbre y lo que está ordenado en el primer Cauildo.

El Señor Regidor Grauiel Escudero de Rocas dixo que se conforma con el primer Cauildo y parecer del Señor Regidot Don Francisco de Aguilar.

E1 Señor Regidor Don Diego Machorro dixo que se siga la costumbre, y éste es su parecer. Y, visto por el Señor Alcalde Mayor, dixo que mandava y mandó se guarde lo botado por la mayor parte y con esto se acauó el dicho Cavildo y lo firmó la dicha Ciudad, Justicia y Regimiento. 31

Indudablemente el susodicho convite y la representación de las comedias en 1644 contribuyeron, en parte, para que el Obispo don Juan de Palafox y Mendoza dirigiese una carta a los curas y beneficiados de Puebla, exhortándolos a que no fuesen a ver los espectáculos dramáticos ni se hallasen en los tules. ${ }^{32}$ Este austero jefe espiritual, siempre muy vigilante por el decoro en las ceremonias y servicios religiosos de su obispado, naturalmente deseaba extirpar todas las prácticas que consideraba malas y, en consecuencia, se sintió compelido a combatir con virulencia excesiva dichos espectáculos. Tuvo también un motivo personal para condenarlos con tanta violencia, pues intentó aleccionar a cierto "Superior de una religión grave", ${ }^{33}$ 
el cual asistía a las comedias y se burlaba de la prohibición que impedía tomar chocolate en las iglesias. ${ }^{34}$ Afirmó Palafox, en una de las más extensas impugnaciones del teatro que jamás se hayan hecho en Iberoamérica, que las comedias eran dañosas e inmorales en grado sumo. Apasionado adversario de las representaciones y los comediantes, se mostró muy duro en la censura, y su desaprobación de las comedias evidentemente se inspiró en varios padres muy contrarios al teatro (en particular el autor jesuita Hurtado de Mendoza), que las nombraban "la peste de la república, el fuego de la virtud, el cebo de la senstalidad, el tribunal del demonio, el consistorio del vicio, el seminario de los pecados más escandalosos, hijos de la idolatría y gentílica ceguedad”. Para apoyar su tesis se sirvió de lo dicho en la Biblia o por ciertos Santos Padres en sus tratados, y luego desarrolló los puntos en que insistía. Mantuvo además que sustentar a los cómicos era fomentar los vicios, que la frecuencia de las representaciones aumentaba los peligros, y que las comedias, ya que las imprimían, no solamente corrompían a los presentes sino a los ausentes también. Objetó asimismo las comedias de la época, porque "todas son veneno que ofrece el deleyte al alma, llevando tan dulcemente a lo malo y con tantos saynetes, conceptos, bayles, gracejo y sensualidad que obran poderosamente". Se oponía también a la práctica de llevar los espectáculos a los templos, que se profanaban con el ruido, las risas desordenadas, los indecentes movimientos de los bailes, la música; y quedaba particularmente disgustado, viendo que los dos sexos podían conversar entre sí, estando sentados juntos en aquel lugar sagrado y no separados como en el teatro público. Concluyó el distinguido Obispo su tesis, dando permiso a sus clérigos para que asistiesen a los diálogos hechos por estudiantes, danzas en que no figurasen mujeres, cañas, estafermos, ${ }^{35}$ sortijas, ${ }^{36}$ máscaras ${ }^{37}$ y otras diversiones de esta clase. Excesivamente severo en su actitud, se expresó en una diatriba, notable por el rigor de su lenguaje, lo mismo que por las curiosas noticias referentes a los otros divertimientos del tiempo. Esta carta, que no se encuentra sino en las dos ediciones de las obras del Iltustrísimo Obispo (Madrid, 1665, tomo v, cap. $\mathrm{x}$ de la Epístola exhortatoria a los curas y beneficiados de la Puebla de los Angeles; Madrid, 1762, tomo III, parte II, cap. X), sólo ha sido aprovechada hasta ahora, al parecer, por Emilio Cotarelo y Mori, quien reprodujo algunos breves extractos en su estudio relativo a las controversias sobre la licitud del teatro en España. ${ }^{38}$ 
Siendo dicha carta un documento de tanto interés para la historia del teatro mexicano como para la del español, la incluyo integra en el presente estudio.

E1 20 de septiembre de 1652 el Virrey Conde de Alba de Liste confirmó los mandamientos de sus predecesores, "despachados de pedimento de la parte del Hospital de San Róque, de la Ciudad de los Angeles, para que los autores de comedias de las que se representasen en la dicha Ciudad, contribuyesen seis pesos de cada una de las que dentro del dicho Hospital se recitasen, y de las de afuera, cuatro pesos, pidiéndome que por ser esta obra de caridad, mandase continuarla, por la necesidad que el dicho Hospital padece..." 39

En el año de 1664 el autor de comedias Jerónimo Ortiz, quien trabajaba en la capital de la Nueva España, entregó una súplica pidiendo que no les cobrasen alquiler ni a él ni a sus cómicos por las viviendas que ocupaban dentro del Hospital Real de los Indios, afirmando "que es estilo muy corriente en la Ciudad de la Puebla y la de Zacatecas, dar casa de valde a una compañía cuando va a representar, por el dueño de la casa de la comedia u hospital, por conocer el aumento que se le sigue por dicha representación..." ${ }_{40}$

Parece que en el año de 1687 se habían ido de la ciudad de México varios comediantes, cuya presencia se requería para dar representaciones, y así María de Celi, autora de comedias, suplicó a las autoridades que compeliesen a volver a Bernardo Pérez, Juan de Dios y Francisco Rascón, los cuales se hallaban "en la Provincia de Tlaxcala y Ciudad de los Angeles". ${ }^{47}$ 

TOMO III

PARTE II

EPISTOLA II

\section{EXHORTATORIA A LOS CURAS Y BENEFICIARIOS}

DE LA PUEBLA DE LOS ANGELES

\section{CAPITULO $\mathrm{X}$}

QVE LOS CVRAS Y SACERDOTES NO VAYAN A LAS COMEDIAS

NI SE HALLEN EN LOS TULES

p. 206 Lícitas son las recreaciones y entretenimientos honestos, decentes y modestos, aún a los muy espirituales, para dar un poco de alivio a las flacas fuerzas de esta miserable naturaleza para que con más brío vuelva a los egercicios santos del espiritu; y en consequencia de esto vemos que el mayor maestro Christo, bien nuestro, a sus apóstoles tal vez les permitía un santo alivio, como quando, volviendo cansados y fatigados del egercicio de la predicación en que habían cogido copiosos frutos, les dijo: (Venid, retitémonos a un desietto para que descanséis un tato) Venite seorsum in desertum locum et requiescite pusillum. 1 Creen algunos que Dios es rígido con sus siervos y que no los deja alentar y es engaño, como vemos en este lugar y en otros; y las santas religiones, con tanto acierto gobernadas, tienen sus horas y tiempos dedicados para alivio del continuo trabajo de su penitente vida, que llaman recreaciones. A mí me notan de demasiado rígido en mis dictámenes, pero no me precio de tal ni quiero que degen los sacerdotes de tener sus licitos y decentes entretenimientos; solamente vedo y prohibo los que juzgo que no dicen bien con el estado sacerdotal, y en éspecial los espectáculos públicos que se especificarán en estos decretos y en particular los de las comedias, por las razones que diré y por ser ellas tan dañosas, como significaré en los párrafos siguientes.

2. El assistir a las comedias los eclesiásticos prohibimos del todo, porque las comedias son la peste de la república, el fuego de la virtud, 
el cebo de la sensualidad, el tribunal del demonio, el consistorio del vicio, el seminario de los pecados más escandalosos, hijos de la idolatría y gentílica ceguedad, que con todos estos títulos y otros más infames p. 207 las difinen los santos en/sus tratados. A ellas les aplica Tertuliano en uno que hizo contra esta peste el primero verso de los Salmos: Beatus vit qui non abijt in consilio impiorum et in via peccatotum non stetit et in cathedra pestilentiae non sedit! 2 ( $\mathrm{i} O$ bienaventurado el vatón que no se fué a la congregación de los impios ni al camino de los pecadores, ni se assienta en la cátedta de la pestilencia!) Y sólo este lugar podía dar materia a un largo discurso, pues no puede difinirse mejor esta miseria que con lo que se encierra en él, porque no son las comedias sino un seminario de pasiones, de donde sale la crueldad embravecida, la sensualidad abrasada, la maldad instruída para cometer pecados. ¿Qué cosa hay allí que sea de piedad y religión? Ver hombres enamorando, mugeres engañando, perversos aconsejando y disponiendo pecados.

3. Sobre el punto de la impiedad, in consilio impiotum, ¿qué se podía decir de las pendencias, muertes y escándalos que han resultado de las comedias? Alli se fraguan y en saliendo se egecutan: exemplo puede ser lo que sucedió en un convento en donde dos desdichados, al tiempo que oían las comedias, riñeron $y$ en saliendo pelearon $y$ al instante quedó el uno de ellos muerto a las puertas de la iglesia donde se hizo la comediá. ¿Qué disposición se le dió a este pobre christiano para una cuenta tan breve $y$ acelerada? Este suceso podía servir de aviso, $y$ bien sangriento, pues fué en la primera, para dejar la segunda, la tercera, la quarta, la quinta. Y en Santa Isabel, otro convento de religiosas, sacaron las espadas y tuvieron cuchilladas. Esto, ¿cómo es posible que se haga sin pecado, sin escándalo, sin tenerse por malo, como algunos quieren persuadir, sin ser digno de predicar contra ello y hacer leyes que lo prohiban, por lo menos, a los súbditos de nuestro fuero eclesiástico y secular?

4. Y llámase justamente la comedia camino de pecadores: $E t$ in via peccatotum non stetit, pues de la manera que la oración, la disciplina, el ayuno, lo es de los justos y de los sacerdotes y religiosos, porque los contiene, los refrena, los humilla, los sujeta a la voluntad de Dios, así las comedias, por el contrario, desenfrenan todos los apetitos sensuales y allí bebe su veneno el alma y sale inflamada del mal,

p. 208 alli se recrean, y se relajan los / sentidos, alli se deleytan las potencias y cobran fuerzas los vicios contra lo bueno y una preparación y propensión relajadíssima a lo malo.

5. $Y$ assí justamente el Espititu Santo en el mismo lugar las llama también cátedra de pestilencia: Et in cathedra pestilentiae non sedit, porque sin duda es cátedra en donde se enseñan las maldades, en donde a la casada le advierten cómo engañará al marido, a la doncella a sus padres, de qué manera se harán sin pena los adulterios, cómo se rendizán al vicio las voluntades. Cátedra de pestilencia, donde se 
enseña a pecar y a que ofendan sus criaturas a Dios con toda destreza y arte, y assí dice San Cipriano: Quid inter haec christianus fidelis facit, cui vitia non licet, nec cogitate? quid oblectatut simulachris libi- dinis, ut in ipsis deposita verecundia audacior fiat ad crimina? Discit et facere, dum consuescit videre. ${ }^{3}$ ¿Qué hace el christiano donde se enseñan los vicios sino aprender a obrar lo que está mirando hacer y recibir el contagio en su alma que está ardiendo en las agenas? A esta causa el Concilio Constantinopolitano prohibe con graves penas a los eclesiásticos y seglares, diciendo: (El seglat que oyere comedias sea descomulgado y el eclesiástico degradado o despuesto de sus ótdenes) Prohibet omnino haec Sancta Synodus univetsalis eos, qui dicuntur, mimos et eotum spectacula, deinde venationum quoque spectationes, atque eas quae fiunt in scaena saltationes perfici: qui secus fecerit: si sit clericus, deponatur; si laicus, segregetur. ${ }^{4}$ Et Conc. Laodic. de Cler.: Non oportet ministros altaris, vel quoslibet clericos spectaculis aliquibus, quae aut in nuptijs, aut in scaenis exhibentur interesse; sed antequam thymelici ingrediantur, surgere eos debere de convivio, et abite 5 ( $Y$ no sólo prohibe los espectáculos públicos, pero que ni en casas patticulates, quando assisten a algunos actos licitos, como casamientos y otros, si huviere comedias no se hallen, sino que se salgan de alli los sacerdotes. primero y con aquellas palabtas: antequam thymelici ingrediantur.) Antes que entren los representantes, porque no se vean dentro de una misma sala sacerdotes del Señor y comediantes, ministros de Dios y

p. 209 de Belial. Y San Cipriano,/ porque un christiano se hizo histrión, que corresponde a lo que ahora comediante, lo descomulgó y echó de la iglesia, diciendo que no se compadecía la pureza de la religión christiana con la impureza de los espectáculos y comedias, juzgando el santo mártir que era nota e infamia de la iglesia que hubiesse un comediante christiano y assí como apestado lo apartaba de los fieles: Puto nec majestati divinae, nec evangelicae disciplinae congruete, ut pudor et honor ecclesiae tam turpi et infami contagione foedetur. 6.

6. Y a esto debió de mirar el negarles la comunión a estos hombres, señaladamente la sagrada religión de la Compañia en muchas partes, la qual, como tan docta y santa, se ha opuesto sumamente a las comedias y escrito excelentes tratados sobre ello por juzgar estos doctos y espirituales varones que no han de participar de la mesa del altar los que siguen oficios tan nocivos a las almas, infames por el derecho y de los quales resultan tantos pecados. Mire Vufstra Reverendísima 7 quál será, lo que éstos hacen en la iglesia. pues sin tanta reprobación no pueden egercitarlo.

7. Y no sólo el ver semejantes espectáculos sino el entrar en tales lugares $y$ teatros se tenía entre los christianos por afrenta, porque se juzgaba por lugar impúdico, infame y vil y donde tenía su magisterio el demonio; y assí dice Tertuliano: Similiter impudicitiam omnem amoliti jubemur, hoc igitur modo etiam a theatro separamut, quod est privatum consistorium impudicitiae, ubi nihil probatut, quam quod 
alibi non probatur; \& paulo post: Quod si nobis ominis impudicitia execranda est, cur liceat audire, quae loqui non licet? \& deinde latissime. 8 Apartámorios de los teatros los christianos por ser el consistorio y tribunal de las deshonestidades donde sólo es bueno lo que en todas partes es malo; y dice excelentemente: es bueno lo que en todas partes es malo, porque el adulterio que en las plazas se castiga, alli se alaba; los hurtos que en todas partes se evitan, alli con eminencia se enseñan; los amores que en todas partes se reprimen, allí se solicitan y aplauden; las trayciones que en todas partes se aborrecen, allí entretienen $y$ divierten; las mentiras que en otras partes son. feas, alli son apacibles y graciosas; finalmente, lo que es delito en la calle, es allí magisterio y alabanza. /

p. 210 8. $\mathrm{Y}$ de aquí funda con eminencia el mismo Tertuliano el desatino de oír lo malo, que no puede hacerse, y aprender lo pésimo, que no. debe egercitarse. ¿No es gran desatino, dice, que vamos a aptender lo que después no es lícito obrar? Si las vanas palabras, añade, no son lícitas, ¿cómo lo serán aprender pasiones impuras y execrandas obras? $\mathrm{Y}$ si es maldad el hacerlo, no será bueno aprenderlo, porque no puede conservar su vida el alma si entra la muerte por los oídos del cuerpo, ni quedarse inocente quando se le introduce el pecado por los ojos. ¿Mancháis, dice, los canales por donde va al espíritu la materia de su. bien o de su mal y queréis que llegue pura? Si malos fueren los medios, no puede ser bueno el fin.

9. Refiere el mismo Tertuliano dos casos notables que sucedieron en su tiempo a dos christianas que entraron en el teatro: que a la una estando en él se le entró el demonio en el cuerpo y salió de allí endemoniada; y exorcizándola después en la iglesia y preguntando al enemigo común, ¿cómo se había atrevido a entrar en aquel cuerpo christiano? Respondió: Constanter et justissime quidem feci, in meo eam inveni. (Justamente lo hice, respondió, porque la hallé en $\mathrm{mi}$ jutisdicción.) Como quien dice: luego que entró en mi teatro, se me sujetó con el ingreso, porque allí yo soy quien mando y todo aquello lo tengo por mi peculio y heredamiento. A otra muger, la noche del mismo día que entró en el teatro le mostraron una mortaja y dentro. de cinco días murió. Ella viviera, si la mortaja que le mostraron después la tuviera presente antes de entrar y en esse caso no entrara. Nam et exemplus accidit, Domino teste, ejus mulieris, quae theattum adijt et inde cum demonio redijt; itaque in exorcismo, cum oneraretur immundus spititus quod ausus esset fidelem aggredi, constanter et justissime, inquit, feci, in meo eam inveni. Constat et alij linteum in somnis. ostensum ejus diei nocte, qua tragaedia audierat, cum ex probatione nominato tragaedo, nec ultra quintum diem eam mulietem in saeculo. fuisse. 9

10. Finalmente, son grandes las ponderaciones que hacen los santos de lo que conviene que los christianos se aparten de estos públicos espectáculos y hicieron de ello tratados enteros Tertuliano, San. 
p. 211 Cipriako y San Juan Crisóstomo, que con/ rara eloquencia y zelo lo pondera en sus homilías. San Agustín en sus sermones y confesiones donde refiere la miserable caída de su amigo Alipio, sólo por ir una vez a los espectáculos: Spectavit, clamavit, exatsit, abstulit inde secum insaniam, qua stimulatetur tedire, non tantum cum illis... sed etiam prae illis a quibus erat adductus. 10 Pero propondré un lugar no menos docto y santo de Salviano en sus libros de providencia, donde después de haber atribuído a los espectáculos las desdichas públicas del mundo, prosigue: Citcumsonabant atmis mutos Cathaginis populi batbatorum et ecclesia Catthaginensis insaniebat in circis, luxuriabatur in theatris: alij foris jugulabantur, alij intus ridebant. Pats plebis erat foris captiva hostium, pars intus captiva vitiorum. ${ }^{11}$ (Cercaban a la Ciudad de Cartago los bárbaros y la iglesia de Cartago, esto es, los christianos se holgaban en los teatros: a unos degollaban fueta y otros se teian alló dentro: parte de los ciudadanos afueta en cautiverio de los enemigos $y$ otia adentro en el cruel de los vicios.)

11. Lloraba este grave autor que, quando el mundo estaba armado contra la $\mathrm{fe}$, quando los enemigos de la Iglesia la perseguían, estuviessen los christianos divertidos $\mathrm{y}$ ocupados en estas vanidades $\mathrm{y}$ miserias, donde es de ponderar para nosotros: Cercaban a la Ciudad los bárbatos y buylaban en la iglesia los cercados. Significando que quando las desdichas públicas son tantas, quando los enemigos triunfan del nombre christiano, hemos ide llorar los sacerdotes en los templos y sólo se ha de oír en ellos el ruido de las disciplinas y no las voces deshonestas y acentos sensuales de los pulgares y bayles; y que al tiempo que el Rey, Nuestro Señor, está en campaña para defender la fe y su corona católica y acaba Dios de llevarnos en la Reyna, Nuestra Señora, el amparo que teníamos en aquella esclarecida virtud y prudencia, mejor parece en el templo de Dios un varón apostólico predicando penitencia que un farsante liviandades; porque andar los seglares cargados de luto por essas calles con tan gran pérdida y los sacerdotes llevar a los templos los bayles, entremeses y comedias, podrán justamente reprehendernos con la sentencia del Espíritu Divino: (Músi-

p. $212 \mathrm{ca} /$ en el lato, importuna nattación) Musica in lucta, importana narratio. 12

12. Y a esto mixa también lo que pondera el mismo Tertuliano: Vicibus disposita res est: nunc illi (gentiles) laetantut, nos conflictamut. Saeculum, inquit, gaudebit, vos tristes eritis. Lugeamus etgo, dum ethnici gaudent, ut cum lugete caeperint, gaudeamus; ne pariter nunc gaudentes, tunc quoque pariter lugeamus. Delicatus es christiane, si et in saeculo voluptatem concupiscis. 13 ¿Quándo, dice, hemos de vivir los christianos llorando? Quando los gentiles viven holgando, como quien aconseja, que ande nuestra procesión por otra parte: advertencia excelente para los eclesiásticos y sacerdotes respecto de los seglares. Mientras los del siglo, dice, ríen, lloremos los eclesiásticos, para que quando ellos comiencen a llorar, comencemos nosotros a reír, porque si 
igualmente con ellos nos holgamos, igualmente con ellos lloraremos. Delicado es el soldado christiano, que aún en esta vida quiere buscar el deleyte, como quien dice, dos primaveras en un año es imposible, como en una misma vida dos diversas juventudes. Querer continuar los deleytes de esta vida con la eterna es imposible. Comedias, y luego cielo sin purgarlo, es sumamente incompatible; menester es, si queremos gozar alli, padecer aquí; porque si gozaremos aquí, padecereroos allí.

13. ¿Pero para qué es necesario cansar con la erudición antigua, de que se podía hacer un volumen inmenso, teniendo en las reglas de los santos la calificación de este género de excesos? En lós opúsculos del seráfico Padre San Francisco, hablando con sus religiosos, dice: Séales prohibido del todo ir a deshonestos banquetes o a espectáculos o plazas o bayles; y a los comediantes por ocasión de la vanidad que representan, no se les dé cosa alguna y' desvélense mucho que ninguno de los de su familia les socorra, ${ }^{14}$ en cuyo lugar se pueden hacer seis ponderaciones excelentes.

14. La primera en aquellas palabras: Penitus interdictus, del p. 213 todo prohibido que hacen ponderación màs eficaz que la/misma prohibición, porque ni les deja causa, color, ni ocasión alguna para que puedan ir a ver semejantes espectáculos ni por venida de superiotes, ni por elecciones, ni por pacificar voluntades y escusar discordias, ni por otra causa alguna.

15. La segunda: que siendo este seráfico varón una imagen viva del amor de Jesucristo y ardiendo su corazón en el de los prógimos, de manera que a todos les quería dar, consolar, ayudar, socorrer, favorecer; pero, en llegando a los comediantes, echó por otra calle la caridad del santo y tomó en la mano el zelo de la justicia, prohibiendo que les diessen cosa alguna por estas representaciones.

16. La tercera: que no solamente prohibió que les diessen algo los religiosos a los representantes por este género de entretenimientos, pero que tampoco ninguno de su familia los socorriesse, porque parece que quiso el santo ver si podía reducir los faranduleros por hambre $y$ con ayunos y mortificaciones, como se suelen conquistar los castillos $y$ fortalezas.

17. La quarta: que no solamente prohibe el que vayan los religiosos a las comedias sino qualesquiera otros espectáculos nocivos; y assí bien se ve cómo prohibiera las comedias en que se mezclen bayles impudicissimos, cuyos nombres no me atrevo a referir por no manchar el papel sobre que escribo.

18. La quinta: que si prohibe el santo el no it a los teatros qualquiera de los religiosos, con ser assí que el defecto del particular no mancha la religión; arguyendo a fortiori, bien se ve quán prohibido será el assistir a ellas las cabezas de la religión y con su egemplo los demás, si sucediesse, que no es creíble. 
19. La sexta: que si el ir a los teatros es prohibido, ¿qué será el traher los mismos teatros a los templos, cosa que tan opuesta es a la decencia con que se deben tratar aquellos santos lugares, destinados $y$ consagrados al culto y reverencia que a Dios se debe? ( $A$ la casa de Dios está vinculada la santidad eternamente) dijo el profeta: Domum luam Domine decet sanctitudo in longitudinem dierum. ${ }^{15}$ ¿Cómo se compadecerá la santidad con la indecentíssima profanidad de los actos p. 214 cómicos? ¿Cómo/las risadas descompuestas con los gemidos del pecador para que son los templos?

20. Y porque en esta parte y sobre este lugar escribió con rara erudición el doctíssimo y religiosíssimo Padre Fray Lucas Vvadingo de la Orden de San Francisco, hijo de la Provincia de Santiago, que le hizo ilustres anotaciones otro docto padre de su hábito y provincia. Véase la del número 23, cerca del fin, sobre este mismo capítulo 4 conde, después de haber con pluma delgadíssima y estilo eloquentíssimo ponderado la ruina que causan las comedias en las almas, introduciendo algunos lugates de santos al intento, volviéndose a los religiosos de su seráfica orden, les dice: Hujus vero sodalitij viti, qui denuo saeculi vale dixerunt solatijs et ipso habitu haec se contempsisse praeferunt, plus caeteris $a b$ hujus modi malorum apothecis procul debent abesse; ne quod ote professi sünt opere detestentut; et quod habitu spondent, factis negent. Hem! decens est locus poenitenti sorori vel fratti theatrum? aequa solatia impudicitiae? Tam ridiculum se exhibet in gesticulationibus vel vanis figmentis pantomimus, quam hajus ordinis fratres inter obscoenas infamias. Ille sexum, hic poenitentiam, habitu fingit; ille personam, hic conditionem, veste mentitur. Quisquis es vel frater aut soror qui his spectaculis absque rubore assides, te orem, te deprecer: considera pactum, conditionem attende, militiam nosce; pactum quod spopondisti, conditionem qua accessisti, militiam cui nomen dedisti: erubesce inter vanitatem tuo statui contrariam, voluptatem contemne, qui cum voluptate mori desideres. Vellem mihi licetet latius per haec evagari, illorumque refellere et pessumdare sensum, qui praestant his vitiotum seminarijs auctoritatem et veluti voluptatum assettores blandi, vel recreationum indulgentes patroni censuram Scripturatum coelestium in advocationem criminum convertant. Nam proh dolot! Eo usque enervatus est ecclesiasticae disciplinae vigor, ut jam non vitijs excusatio, sed auctoritas detur et obscoenae scenae habeant non reprehensores, sed tutelates. 16 (Los religiosos de esta orden, que han dejado los consuelos del siglo y lo manifiestan en la pobreza del hábito, más que todos los otros se deben recatar y guardar de esta multitud de daños y ruinas, porque si no, parecerá que lo que profesaron con las palabras, aborrecen con las obras y niegan con el hecho lo que of tecen con el hábito.

p. 215 ;O dolor! ¿de-/ cente lugat es a una penitente monja o frayle un teatro? ¿Honesto consuelo la impudicicia? Tan tidículos patecen los religiosos oyendo, como los farsantes representando, pues los unos y los otros fingen; los religiosos en el hábito parecen frayles, y no lo son 
en la acción; y los representantes príncipes y teyes en la reptesentación, picatos y viles en el egercicio. Qualquieta que seas, frayle o monja, que sin vergüenza assistes a las comedias, yo te pido y ruego que consideres el pacto que ofreciste, la condición con que entraste, la compañia en que te alistaste; avergüénzate de una vanidad contraria a tu mismo estado, desprecia essa vana alegría al vivit si quieres tenerla verdadeta al morit. Quertía que me fueta licito proseguit más largamente sobre esto y reprobar y pisat los dictámenes de aquéllos que a este género de vicios aplican su autotidad y son sus blandos y suaves defensores y abogados, buscando lugares de la Escritura con que volvet por semejante maldad. iAy dolor! que a tal estado ha llegado el perdet sus fuerzas la disciplina ectesiástica, que ya no sólo no se reprueba sino se autoriza lo malo y las obscenas comedias no tienen tantos reprehensores como defensores.) Hasta aquí, este religiosíssimo y doctíssimo padre.

21. Dejo otros muchos lugares por suponer que son bien presentes a los leidos y he dicho éstos por habérseme of recido a la pluma, pero tengo por conveniente responder a las objeciones que suele hacerse a esta doctrina en favor de las comedias con la brevedad posible, porque todo esto es defensa de este sentir, aunque sé y veo que hay tantos que abogan y defienden las comedias, y con buen zelo, claro es; pero no basta el zelo, que se juzga bueno, sin examinarle bien y a la luz del desengaño que siempre mira y sigue lo mejor.

22. Dicen que no son estas comedias de las que hablan los santos y esto no se puede decir sino midiendo lo que entonces ponderaban y ahora pasa, pues si unos mismos daños ponderaban y unos mismos daños vemos, creer debemos que de una misma materia y pecado hablaban.

23. Ponderaban los santos el dispendio y riesgo de la vida, como hemos visto, $\mathrm{y}$ en este punto ya se ve, $\mathrm{y}$ hemos dicho quántas pendencias, muertes, desdichas han resultado de encuentros que se han tenido

p. 216 en las comedias de zelos que alli se/han formado, de deseos que alli se han concebido y fomentado.

24. Ponderaban los santos el dispendio y pérdida de la hacienda quando dice San Águstín, hablando de los que dicen que es caridad el sustentar los representantes quando pagan al entrar: (Esto no es, dice, sustentat al hombre sino al vicio, no a la persona sino al cómico) Donate res suas histrionibus vitium est immane, non vittus. Qui enim histrioni donat, non homini donat, sed atti nequissimae. ${ }^{17} \mathrm{Y}$ San Juan Crisóstomo, de quien se queja más, es de los superiores y súbditos que les pagan, porque éstos son los que los sustentan, pues si no les pagaran, no representaran; y dícelo con gravissimas palabras que pongo a la letra: (No dejan, dice el santo, de pecat los representantes, peto vosotros con pagarles fomentáis este pecado $y$ assi sois cabeza $y$ causa original de todos los que ellos hacen) Et haec dico, non ut illos a crimine videar vindicare, sed ut vos discatis initium et caput iniquita- 
tis hujus vos esse potissimum, qui totam ptorsus dem in tam ridicula, tamque pernitiosa voluptate consumitis. $18 \mathrm{Y}$ a esta causa un grave autor de la Compañía de Jesús, que escribió de esta materia con muy grande erudición, afirma que peca mortalmente el que entra pagando en la comedia y no el que entra sin pagar, porque el que paga sustenta a los comediantes y el serlo tiene él por pecado grave y el que no paga sólo lleva consigo el peligro de la materia presente: Itaque praetet partialem sustentationem, respondentem pecunijs singulorum; singulae pe-. cuniae sunt objectum per se amatum actu, qui est peccatum mortale in histrione; ergo singulae concuttunt per se ad totam illam actionem et consequenter singuli peccant, mottaliter. 19 . Véase, pues, la hacienda y plata que se pierde cada día en fomentar este daño al tiempo que están tantos pobres desnudos y necesitados de este debido socorro y. véase quántos hombres, por irse tras una representanta, se han perdido y desnudado a sus propias mugeres e hijos para vestirlas a ellas, y se conocerá quán bien se ajusta a esta doctrina de los santos y que tóda es una la materia que merece una calificación.

p. 217 25. La ponderación con que hablan los autores modernos/de la comedias es muy semejante a la que hablan los santos de las de su tiempo, porque, dejados muchos tratados que se han hecho contra ellas, donde se hallarán éstos y otros muchos lugares, dice este mismo autor: Et quidem dedicori christianotum este Ovidium Roma pulsum authoritate Augusti propter artem amandi; multos autem obscaenissimos libros editos in lucem $a b$ hominibus christianis et, quod sanguineis lachrymis esset deplotandum, interdum a sacerdotibus. Mille comoedias fertur composuisse unus et viginti earum volumina evalgasse, quibus pluta peccata invexit in orbem, quam mille doemones; nec tamen suplicium ullum cui ex his authotitatibus est inflictum. $20 \mathrm{Y}$ hablando de un hombre que había hecho mil comedias, ha hecho, dice, más daño este hombre que huvieran hecho mil demonios; y si no entendiera las autoridades de los santos de este género de espectáculos, no hablara de esta manera.

26. Y es certíssimo que personas muy graves y santas assientan que las calamidades públicas las han causado por la mayor parte las comeđias, no sólo por las ofensas a Dios, que con ellas se han mezclado, sino porque han encendido la sensualidad y despertado los trages deshonestos y enervado la fortaleza y virtud y manchado el honor $y$ el valor de la nobleza; y el día que nos hallamos perdidos en lo moral, naturalmente seremos triunfo de nuestros enemigos en lo militar y político, como ha sucedido a quantas naciones ha habido en el mundo, de que son muy patentes los egemplos.

27. Antes, habiendo yo considerado con atención los espectáculos antiguos y los modernos (en tiempo que estaba más desocupado), formé dictamen, y en él estoy, que fuera de algunos, como eran los de la diosa Flora entre los gentiles, todos los demás son excedidos sin 
comparación de los nuestros en lo que mira a la ruina de las costumbres, pecados y daños públicos.

28. Lo primero: porque los espectáculos antiguos costaban grande suma de ducados, y había alguno que costaba millón y medio de hacerse, como lo advierten Lipsio y otros, ${ }^{21}$ y assi se hacian raras p. 218 veces en un año. Ahora con cinquenta pesos se/hace una comedia cada día, donde se pierden las almas; y esta frequente repetición de peligros es la que hace repetición frequente de caídas y pecados.

29. Lo segundo: porque los espectáculos antiguos, unos causaban admiración, como el ver correr los carros teatrales en el Imperio Griego y ver batallas navales en la tierra, haciendo para esso unas grandes lagunas en el Romano; otros horror, como matarse unos hombres a otros que ya estaban condenados a muerte o echarse los corniessen las fieras; otros dureza de corazón, como el de los gladiatores; otros gusto, como de pelear unos con otros los animales; 22 pero los de hoy, todos tiran a arrebatar los sentidos y robatlos y llevarlos a lo malo, deleytoso, breve, fácil, más propio y congruo a nuestra naturaleza; con que para Dios son de mayor daño y ruina quanto más fácilmente se apega el alma a estos daños y se deja cautivar de lo sensual del deleyte.

30. Lo tercero: que todos los espectáculos antiguos no se podian gozar si no los iban a ver y assí sólo bacían daño a los presentes, pero las comedias, como se han reducido a impresiones y se pueden leer por los ausentes, no hay doncella tan retirada, ni casada tan guardada que no pueda beber y morir a este veneno, $y$ assí inflaman la imaginación $e$ inflaman $e 1$ apetito y obscurecen la razón y de esta ruina se han visto grandes y deplorables egemplos. Impudicae comediae publicis in theatris aguntur, versantur in jutenum senumque manibus, virorum atque mulierum, quibus omnes anguli sunt pleni. Contaminant quidem mortalium animos, hautientes cum catminum suavitate venenum cortumpens venas ignemque caecum quo saepe catpuntur. Authores horum librorum esse in peccato mottali scandali activi recte asserunt authores, qui histriones peccati damnant. ${ }^{23}$

31. Lo quarto: que en los espectáculos y comedias antiguas no guiaba tanto al daño de las costumbres la forma de la locución $y$ frase como ahora, porque no tenía toda la modulación, acento y consonancia que hoy tiene con estos versos; y assí se ve que las de Terencio o Plauto y otros, leídas, ni dañan, ni divierten, ni persuaden, pero

p. 219 las de estos infelices / tiempos todas son veneno que ofrece el deleyte al alma, llevando tan dulcemente a lo malo y con tantos saynetes, conceptos, bayles, gracejo y sensualidad que obran poderosamente; y assí tengo por muy cierto que es esta peste doblado perniciosa en estos siglos que en los pasados.

32. La otra escusa de las comedias suele ser 24 que están ya permitídas y recibidas y éssa, ni es bastante para los seglares y menos para los que somos eclesiásticos, porque la permisión pública no justifica lo 
que fuere malo dentro de la misma acción, pues puede haber causa para toletatlo y no haberla para usarlo. También se toleran los lupanares y es pésimo su egercicio; con un marco se castiga a un amancebado, luego, ¿con un marco puede amancebarse el hombre? Esso, no; las leyes políticas, aunque tal vez toleran po: otros fines lo malo, no lo aprueban; se compadecen de nuestra fragilidad y sufren algunas cosas, porque esta perdida naturaleza no se desenfrene en otras. La sinagoga se permite en Orán y en todas las demás partes se quema justamente al judayzante. Bien puede el superior tener causa a la tolerancia y tenerla el súbdito a la acción, y mucho más en los eclesiásticos en los quales son más rigurosas las leyes, y lo que se permite a los seglares no hemos de tener por lícito a nosotros. La tela y el brocado se per-

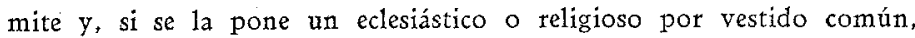
es grande relajación, porque lo concedido al un estado, le es al otro prohibido.

33. $\mathrm{Y}$ a esto mira lo que pondera un autor muy grave hablando de las comedias: Jam scaena ubique renovata est, ubique comoedias spectat uterque sexus; quodque longe impudentius est, ipsi sacetdotes et praesules, quorum etat officium omnino prohibere. ${ }^{25}$ ( $Y a$, dice, los espectáculos antiguos se renuevan y de todos sexos concutten a las comedias, y lo que es más lastimoso, allá van también los mismos sacerdotes y sus supertores, cuyo oficio eta prohibit lo que mandan hacer y van a ver.). Y esto mismo lloró primero San Cipriano con estas elegantes y breves palabras: Jam non vitijs excusatio, sed authoritas datut, 26 Véase a Gaspar Hurtado, donde afirma: Clericos et religiosos

p. 220 peccate mortaliter scaenas/spectantes, vel comoedijs assistentes, ibi assetit; existimo igitur omnes clericos in sacris, item et omnes religiosos peccare mortaliter, quoties intersunt turpibus comoedijs. Haec conclusio non est contra doctores adductos, quia ipsi clericos excusant si scandalum cesset; quod non cessate probabo; teligiosos autem minime excusant. $27 \mathrm{Y}$ assí los superiores, los sacerdotes y los hombres graves $\mathrm{y}$ consagrados a Dios, quando concurren a las comedias y van a autorizar lo que deben prohibir, no sólo a lo malo se da escusa sino fuerza, no sólo defensa sino aprobación; viene a ser la transgresión ley y el pecado premática.

34. Ni tampoco basta otra razón muy común, que es decir, que no siente daño una persona en assistir a las comedias, porque se responde con otras tres más evidentes y claras que la poca luz que tiene quien tanto fía de sí.

35. La primera: que basta y sobra para evitar este daño el poderlo incurrir, pues por lo menos es peligro; y el Espíritu Santo nos ordena nos apartemos del peligro, si queremos no enlazarnos en el daño: Qui amat periculum peribit in illo. 28

36. La segunda: porque deseo saber ¿quién es tan santo, tan puro, tan perfecto que pueda sentir de sí que de tres, quatro y cinco conedias en breves días saldrá con alma tan limpia, tan pura, tan santa, 
tan perfecta como entró a ellas? Burla de éstos San Juan Crisóstomo en el lugar que sigue: Audiant cutiosi, qui pulchtitudines considerant alienas: audiant, qui spectaculis insaniunt in theatris, qui ad excusandas excusationes in peccatis dicunt; expectamus quidem, sed nithil nocemut. David talis ac tantus laests est et ta te putas non posse laedi? Ille nocumen passus est, qui tantam habebat spiritus gratiam, et te quomodo credere potero sine vulnete evasisse? Et ille quidem in solatio domus suae, tu autem in theatro, ubi et locus condemnat animam sapientis, in quo cum tanta sint praecipitia, tantae cortuptelae, quomodo possum tibi ctedere, quod a talibus bestijs vulnetatus non sis? Num quid lapideus es, aut ferreus? Igni conjungetis et non atdebis? 29 Pregunta: ¿si se tienen por más fuertes que David? Y luego añade: si los que están muy lejos de las voces de las sirenas y de las comedias, músi-

p. 221 cas, bayles, deleytes, apenas pueden consigo en la tentación, ¿quién / es tan valiente qué en médio del fuego no se abrasa y, lavándose con pez, no se mancha? El arte, el estudio y el cuidado ponemos en recrear los sentidos y potencias, ¿y pensamos de este fuego temporal escusar el fuego eterno? David tantus ac talis laesus est et tu te putas non posse laedi? (Cayó David, tan gtan santo, en la ocasión, ¿y tú te tienes por tan santo que imaginas no caet?) El que a sí mismo se tiene por tan fuerte, flaco es, ya ha caído postrado de la soberbia y no le parecetá a él que ha de caer, porque ya está tendido en el mismo vicio. ¿Por ventura ignoramos que somos más prontos a lo malo que a lo bueno? En la soledad téme y tiembla el solitario, ¿y en el teatro se tiene el profano por seguro?

37. La tercera: la del escándalo que causan aquéllos que mandan hacer comedias, las permiten o las pagan dentro de los mismos templos a los que las van a ver: Existimo praeterea homines peccate mortaliter si permittant suas uxores, filios aut filias haec adite theatta. Haec conclusio sequitur ex superiori. Ratio est, quia ista spectacula sunt ingenti occasioni peccandi: ergo patet familias tenetut ab ea occasione servare domesticos, alioquin familiam administrat contra dictamen tectae tationis. 30 Porque, quando bien el que esto dispone y ordena sea tan puro que él no incurra a la vista de la tentación en el pecado, ¿quién ha fiado a los demás? ¿Por ventura, antes de entrar huvo quien les afianzasse, assegurasse o digesse bien podéis holgaros, que aunque se deleyte el oído con la música, la vista con los impúdicos bayles, la imaginación con las feas representaciones, el entendimiento con lascivos conceptos, no pasará nada a el alma? Y esto mucho más en religiosos y sacerdotes y esposas de Jesuchristo, que con tanta pureza debemos conservar las nuestras, pues en nosotros, quanto ha de ser más retirada y abstraída la vida, suele ser más aprehensiva la imaginación, más importuno el tentador, más acosado y combatido el espíritu. ¿Qué pared de bronce hay entre el pensamiento y el consentimiento, entre éste y la culpa, entre la culpa y la pena? Y assí, esto sólo bastaría pata que los que somos cabezas de to eclesiástico apartássemos como el fuego 
esta peste de nosotros y de nuestros súbditos, que los seglares en lo p. 222 político pueden alegar algunas razones que debemos/creer las tendrán muy bien miradas para tolerarlo, pero nosotros ningunas.

38. Añado a esto el llevar estos actos profanos y livianos a los templos donde los mismos ángeles y setafines, por la assistencia de los divinos oficios y el Santíssimo Sacramento del Altar, están con gran reverencia adorándole: ¿Allí se han de oír el ruido de los pulgares, los infames movimientos de los bayles, las risas desordenadas, los conceptos deshonestos? ¿Allí las guitarras, la música, las canciones, despertando torpes imaginaciones, infamando las paredes santas y suelo sagrado donde están los difuntos desengañando a los vivos y afligiéndose las imágenes en los mismos altares de verse de esta suerte profanadas? Quamvis magisttatus fotte possent excusati in permissione comicorum; tamen excusati non possunt, si eos permittant in templis agere comoedias. (Sanct. Thom. 2, 2 q. 168, art. 2.) Recte dixit ludum tatione loci posse esse peccatum. (Silvest. lud. 4.) Dixit comoediam tutpem non posse absque peccato mortali agi in templo, ob quod id magistratus tenentur, interdicere, quia facile possunt. Miror interdum a personis religiosis histriones accersi in sua templa, amatotia acturos. Quod si sactificiotum matetiam indigne tulit Chtistus in antiquo templo divendi, qua tatione ferat cotam se in templis fabulas turpes, choreas inhonestas, obscaenas cantinelas, populo frequenti in templo accepturo occasionem peccandi, in quo erant peccata deflenda? Curate item debet magistratus ne in celebranda christiani corporis solemnitate agatur aliquid minus honestum. Satis doleo in partem celebritatis tam imputas personas acciri. Item daturi sunt opetam praelati, ut histriones, nisi desetant attem scaenicam priventut christi corpote, mote publici peccatoris. ${ }^{31}$ ¿Qué pendencias, qué conversaciones, qué disgustos, qué pecados, qué injurias no se dicen, no se hacen en estos actos profanos? Los hombres hablando con las mugetes cerca de ellas y ellas pendenciando entre sí indecentíssimamente, como sucedió en estas ocasiones, dando materia a la pública murmuración de los seglares, siendo cierto que es sin comparación más arriesgada la ocasión de los lugares en los templos que en los teatros públicos, en los quales la vergüenza misma ha separado a los oyentes y no pueden hablatse las mugeres con los hombres y hay aposentos divididos; pero en las iglesias, assí p. 223 como todo es/desorden y turbación al resolverlo, todo es también confusión, desorden y pecado al proseguirlo, porque están sin división alguna arriesgados a las indecencias y ofensas de Dios, que más fácilmente pueden creerse que decirse.

39. ¡ Ojalá que no huviera tantos malos egemplares que poder alegar de los excesos que cada día suceden en semejantes juntas, de que hay largas relaciones en los libtos que contra estos abusos hay escritos y tenemos obligación los superiores a zelar lo que vemos digno de enmienda y a velar sobre nuestro ganado, reformando lo que juzgáremos digno de reformación, sin disimular por humanos respetos nada de que 
se nos haya de hacer cargo. Varios son los dictámenes de algunos prelados: unos afectan la apacibilidad, el agrado, el no poner mandatos por no causar inquietud, ni desconsolar por conservar la paz; otros cuidan mucho de su aprovechamiento espiritual, dándose a la oración y meditación, sin cuidar demasiado de la assistencia y gobierno de sus ovejas, como hacía un prelado, a quien San Juan Damasceno escribió estas gravíssimas palabras: Quid est, pater, quod tibi soli vigilas et his pro quibus priotem exigendus es rationem, tam inerti secutitate dotmis? ¿Prelado, padre, pastor, no me dirás en qué afianzas la seguridad de tu conciencia, quando todo eres para ti, nada para tus súbditos? Creerás que estás muy despierto y te engañas, porque estás para ti muy dormido, porque la primera cuenta no ha de ser tuya, sino de los súbditos, ¿cómo la darás si de ellos no la tienes? Buena es la oración, la meditación, la mortificación, la santidad en que aquel prelado se ocupaba, buena era para sí y era mala, porque no cuidaba de sus súbditos. Por esto 1lamó Christo ángeles a aquellos siete prelados, que escribió siete cartas con la pluma del Aguila Juan; 32 y llamando ángeles a aquellos siete prelados, dijo que todos los prelados han de ser ángeles; y aun David dijo: Qui facis angelos tuos spiritus. ${ }^{33}$ Que Dios hacía espíritus a sus ángeles, por quien se entienden los prelados, porque el espíritu, de nadie es menos que de sí; informa al cuerpo, dale aliento, dale vida y suele ser esclavo de lo más vil que tenemos, siendo dueño. ¿Y qué tiene para sí? sólo el trabajo de animar al cuerpo

p. 224 noche y día, / y para sí no tiene nada; éste es el prelado; con Dios no ha de hablar si hace falta a sus ovejas. Aun Christo vemos, que dejaba la quietud de la oración por acudir al consuelo de las turbas que le buscaban, como notó Cayetano en el Comento de San Lucas: Quamvis quietis causa ad orationem secesisset; devotione tamen tutbarum vincitur. ${ }^{24}$ De manera que aquel Prelado Divino, vencido de la obligación de su oficio, dejaba la quietud de la oración, que es lo que se suele decir dejat a Dios pot Dios, esso debemos los prelados.

40. Heme dilatado tanto en este discurso, no por zelo indiscreto o demasiada ansia de reformación, de que tanto me han notado, pues es notorio que, después que vine a estas provincias, jamás me he metido ni hablado palabra en cosa que no me toque, porque nadie ha menester, ni desea tanto ser corregido como yo; pero porque cierto superior de una religión grave, que assiste mucho a las comedias, habiendo sentido mal de mi zelo, se ha opuesto a.lo que tengo ordenado, diciendo en mi iglesia y otras, que ¿por qué yo probibía que en las iglesias se tomasse chocolate? Fundándome en San Pablo, que dice: Numquid domos non habetis ad manducandum et bibendum, aut Ecclesiam Dei contemnitis, ${ }^{35}$ ¿había de mandar este provincial y egecutar lo contrario en sus iglesias? $Y$ porque yo no gustaba de que los clérigos fuessen a las comedias, ¿las había de fomentar?, razones dignas de satisfacerse con este discurso, para que todos vean en qué me fundo para prohibir 
las comedias y los demás espectáculos a que ordeno que no assistan mis súbditos en esta carta exhortatoria.

41. Guárdese también nuestro edicto en que se prohibe a los sacerdotes que no vayan a los tules, $36 \mathrm{ni}$ jueguen, ni intervengan en ellos con mugeres, pena de cinquenta pesos; y si esto no lo puede, ni debe hacer sacerdote, quánto menos el cura o beneficiado; y assimismo el Concilio Megicano, en que prohibe que no se juegue a los naypes: 37 pero podrán entretenerse a los demás juegos de tablas u otros qualesquiera que sean honestos con la conveniente moderación y decencia./

p. 225 42. Los públicos espectáculos de las comedias, pestilencia de estos siglos, como dejo probado, y las demás fiestas en que se mezcla crueldad, como son toros o voladores, que tanto aborrece la iglesia, los santos y cánones sagrados, 38 mucho más lo deben huir los eclesiásticos, gobernándose en todo por su espíritu. Por tanto, ningún eclesiástico, y mucho menos los beneficiados, vaya a este género de fiestas, pena de veinte pesos, como se ordena por nuestro edicto; pero a los diálogos honestos, que hicieren estudiantes, danzas en que no intervengan $\mathrm{mu}$ geres, cañas, estafermo, sortija, máscara y otras de este género, no se les prohibe el verlas, sino el entrar en ellas; aunque les exhortamos a la mayor perfección y decencia de su estado, huir de lo vano, como transitorio, seguir y profesar lo bueno, como sólido y eterno.

43. No se vea en los labios de los sacerdotes y más de los beneficiados el nombre del Señor, sino pata alabarle y adorarle y edificar a los fieles; y el vicio del jurar tan infame, aborrecido e indecente, no solamente lo huyan, sino que del todo en sus partidos io ahuyenten, éste y el de las maldiciones, que unos a otros se echan los seglares y es el más frequente en las casas; persigan mucho estas ponzoñosas y ruines sabandijas, verdaderos nabuyaques 39 de las almas; y el párroco viva tan esento de incurrirlas que pueda con libertad predicar y reprehender a los que se hallan lastimados de estos vicios.

(Nótese que en el original de esta Carta no se hallan los 39 números primeros de este Capítulo $\mathrm{X}$ y los tres últimos son terminación del IX antecedente. Esto y el ver en el discutso tanta copia de autoridades y razones con diferencia de todo lo demás de la Catta arguye no haberle escrito el siervo de Dios para este lugar, sino con otro motivo y en tratado diferente; y por esso le vemos hablar en el número 6 con un religioso grave que no nombra y en el 40 significa el motivo que le dió otra persona de autoridad para tratar el asunto con tanta extensión. El haber adaptado aquel escrito a la Carta presente fué sin duda acción del Reverendíssimo Padte Fray Joseph de Palafox, pues consta de un recibo que firmó a 13 de diciembre de 1660 .

p. 226 y hoy existe en el Ar / chivo de Carmelitas Descalzos, haber llevado de él, entre otros papeles del venerable Obispo, un manuscrito contra las comedias, que no se encuentra en otra parte de los tomos de su colección: lo que arguye con claridad que, logrando la ocasión que le ofrecía el prohibir el zeloso prelado en este lugar la assistencia de los 
sacerdotes a los públicos espectáculos y comedias, incorporó en él su discurso, aunque hecho a otro propósito, para que se viessen los graves fundamentos de razón y autoridad que le assistieron para establecer determinación tan justa. Pero se advierte que muchas de las autoridades, que el venerable siervo de Dios citaba y ponía a la margen, las introdujo el Reverendissimo Palafox en el cuerpo del escrito, aunque por descuido del impresor no se colocaton con el orden que su contexto pedía, lo que se ha procurado remediar en esta impresión, reduciéndolas a los lugares que les corresponden, sin añadir ni quitar cosa alguna, como cualquiera podrá ver.).

HaRvey L. Johnson, Northwestern University. 


\section{NOTAS SOBRE EL PRIMER SIGLÓ DE TEATRO EN PUEBLA}

1 Eduardo Gómez Haro sólo da, para el período considerado en este estudio, información relativa a los años 1613 y 1626 . Véasse su Historia del Teatro Principal de Puebla, Puebla, 1902, pp. 8-10. Su estudio titulado "E1 teatro en Puebla en el siglo XVII", Divulgación histórica (México, vol. III, núm. 8, pp. 400-408), es una copia exacta de los dos primeros capítulos de la obra susodicha, pp. 8-23.

2 Rafael Altamira y Crevea, Historia de España y de la civilización española, Barcelona, III, pp. 357-360, 397-400; Sister M. Francis de Sales McGarty. The Allegorical and Metaphorical Language in the Autos Sacramentales of Calderón. Washington, 1937, p. 17.

3 Juan Corral fué citado en el grupo de varios actores que cobraron dos mil pesos por la tepresentación de dos comedias el día y la octava de la fiesta del Santísimo Sacramento, celebrada en la capital en el año de 1601. Véase Actas de Cabildo de la Ciudad de México, México, 1899. XIV, 258. y mi estudio "Nuevos datos para el teatro mexicano en la primera mitad del siglo XVI: referencias a dramaturgos, comediantes y representaciones dramáticas", Revista de filología hispánica, 1942, IV, 131.

4 Libro de Cabildos, 1597-1605, núm. 13, foja $38 \mathrm{f}$, en el Archivo General del H. Ayuntamiento de Puebla de Zaragoza. Quiero expresar aquí mi agradecimiento al licenciado José Basilio de Unánue, Secretario General del H. Ayuntamiento de Puebla, por los muchos favores que me dispensó mientras trabajaba en el Archivo. Quedo también muy agradecido al señor Luis H. Elizondo, Bibliotecario del Archivo, quien con suma bondad me facilitó la re. copilación de datos sacados de los Libros de Cabildos de Puebla.

5 Ibid., fojas $38 \mathrm{v}-39 \mathrm{f}$.

6 Ibid., foja $39 \mathrm{f}$.

7 Littetae annuae, Puebla, 1599, núm. Méx. 14, fol. 227 r 227 v, en el Archivo General de los Jesuítas en Roma (de copias fotostáticas en la colección del señor profesor Herbert E. Bolton, de la Universidad de California). Para una descripción de esa colección de copias, véase el artículo del señor Peter $M$. Dunne, "Jesuit Annual Letters in the Bancroft Library", Mid-Ametica, 1938, XX, 263-272. E1 Padre Francisco Javier Alegre da también noticias sobre dicha festividad en Puebla. Véase su Historia de la Compañía de Jesús en Nueva-España, México, 1841-1842, I, 382. 
8 Andrés Pérez de Rivas, Corónica y historia teligiosa de la Provincia de la Compañía de Jesús de México, 1, Libro IV, cap. 5 (de una copia becha a mano en la Biblioteca Newberry, Chicago, del manusctito original [1654] que está en la Biblioteca del Congreso, Washington, D. C.) Para una discusión pertinente a los manuscritos y la edición impresa de la historia del Padre Pérez de Rivas, véase Jerome V. Jacobsen, "The Chronicle of Pérez de Ribas", MidAmerica, 1938, XX, 81-95.

9 El sevillano Gonzalo de Riancho, autor de comedias (empresario), contrató con el Cabildo de México dar representaciones en la capital en 1595 , ¿1601?, 1612, 1616,1617, 1618 y 1619. Se mencionó su compañía por primera vez en 1595. La compañía de. Alonso Velázquez se quedó menos tiempo en la Nueva España, trabajando en la capital en los años 1601 y 1603. Véase Johnson, op. cit., y José Rojas Garcidueñas, El teatto de Nueva España en el siglo XVI, México, 1935, pp. 111-113.

10 Libro de Cabildos de Puebla, núm. 13, foja $221 \mathrm{v}$.

11 Ibid., foja $222 \mathrm{f}$.

12 Del General de parte, VI, $289 \mathrm{v}$, impreso en el Boletin del Atchivo General de la Nación, 1944, XV, 114-115.

13 Libro de aranzeles, ordenanzas, vandos y metcedes de tiertas, aguas $y$ pedreras, núm. 22-9, foja 213, Archivo de Puebla.

14 Libto de Cabildos de Puebla, 1613-1620, núm. 15, foja 60 f.

15 Ibid., foja $61 \mathrm{v}$.

16 Para datos concernientes a la tatasca véase Johnson, op. cit., p. 128.

17 Libro de Cabildos de Puebla, 1613-1620, núm. 15, foja $102 \mathrm{v}$,

18 Ibid., foja $103 \mathrm{f}$.

19 Ibid., foja $190 \mathrm{f}$.

20 Nota escrita al margen de la citada foja $190 \mathrm{f}$.

21 Actas de Cabildo de la Ciudad de México, XXII; libro xxii, p. 101.

22 Libro de Cabildos de Puebla, 1620-1626, núm. 16, foja $101 \mathrm{v}$.

23 Ibid., foja $323 \mathrm{v}$.

24 Ibid., núm. 17, foja $14 \mathrm{f}-\mathrm{v}$.

25 Ibid., foja $25 \mathrm{v}$.

26 Ibid., foja $27 \mathrm{f}$.

27 Actas de Cabildo de la Ciudad de México, XxIv, libro xxvii, p. 234.

28 Del General de patte, VII, $185 \mathrm{v}$, impreso en el Boletín del Atchivo General de la Nación, 1944, XV, 117-118.

29 Ibid., $219 \mathrm{v}$, en el Boletín, pp. 118-119.

30 Ibid., 283 v, en el Boletin, p. 120.

31 Libro de Cabildos de Puebla, 1644-1646, núm. 21, fojas $1 \mathrm{f}-9 \mathrm{v}$, passim.

32 Don Fray Juan de Zumárraga, primer Obispo de la Nueva España, prohibió las representaciones poco honestas que se daban en la procesión del Corpus. Véase Enrique de Olavarría y Ferrari, Reseña histórica del teatto en México, 2 a edición, México, 1895, I, 12.

33 Sin duda el Obispo alude a un Superior de la Compañía de Jesús. Para la historia de sus pleitos con los jesuítas véase Pérez de Rivas, op. cit., 
México, 1896, I, 151-205; Antoine Arnauld, Histoite de Dom Jean de Palafox, évêque d'Angelopolis et depuis d'Osme et des diffetens qu'il a eus avec les PP. Jesuites, 1690; Genaro García, Don Juan de Palafox y Mendoza, Obispo de Puebla y Osma, Visitador y Vitrey de la Nueva España, México, 1918, pp. 143-203; José María de Eguren, Palafox y los jesuitas, Madrid, 1878.

34 Tomás Gage reparó en la práctica de las mujeres de Chiapa, que se hacían servir chocolate caliente durante la misa. El Obispo don Bernardino de Salazar, deseoso de extirpar los vicios, prohibió que se bebiese o comiese dentro de la iglesia so pena de ser excomulgados los culpables. En consecuencia de esto, cierta dama, según los rumores, hizo administrar al jefe espiritual veneno en una taza de chocolate. Véase $A$ New Survey of the West-Indias or the English Ametican his Travail by Sea and Land, $2^{\text {a }}$ edición, impresa por $\mathrm{E}$. Cotes y vendida por John Sweeting, Londres, 1655, pp. 102-103. El autor de la Relación verídica, manuscrito inédito del año 1647, llamó la atención sobre que los Padres de la Compañía daban chocolate a las mujeres en la iglesia. Véase Genaro García, op. cit., p. 195.

35 estafermo-"Figura giratoria de un hombre armado, con un escado en la mano izquierda, y en la derecha una correa con unas bolas pendientes o unos saquillos de arena. Colócâse en una cartera y corriendo los jugadores e hiriendo con una lancilla en el escudo, se vuelve la figura y les da con los saquillos o bolas en las espaldas si no lo hacen con destreza." Véase Diccionatio de la lengua española, Real Academia Española, décimasexta edición.

36 correr sortija-"Ejecutar el ejercicio de destreza que consiste en ensartar en la punta de la lanza o de una vara, y corriendo a caballo, una sortija pendiente de una cinta a cierta altura." Ibid.

37 máscata- "Festejo de nobles a caballo, con invención de vestidos y libreas, que se executa de noche con hachas, corriendo parejas." Véase Diccionatio de Autoridades.

38 Bibliografía de las controversias sobre la licitud del teatro en España, Madrid, 1904, pp. $495-496$.

39 Del General de parte, X, p. 133, en el Boletin del Archivo General de la Nación, 1944, XV, 121.

40 Ibid., XI, p. 243, en el Boletin, p. 130.

41 Ibid., XVI, p. 14, en el Botetin, p. 136. Juan de Dios figuraba ya entre los cómicos que actuaban en el Coliseo de México en 1683 . Véase Olavarría y Ferrari, op. cit., 1, 20. 


\section{NOTAS SOBRE LA CARTA DEL OBISPO DON JUAN DE PALAFOX Y MENDOZA EN LA EDICION DEL ANO 1762}

1 Matc. 6, v. 31.

2 Psalm. 1, v. 1; Tertul., t. 2, lib. De Spect., p. 251, lit. B, cap. 3, edit. París, 1584.

3 D. Cyprian., De Spect., p. 341, edit. Paris, ann. 1726.

4 Concil. Constantinop. 3, Can. 51, Collect. Labb, tom. 7, column. 1371, edit. Venet., ann. 1729.

5 Concil. Laodic. de Consecrat, dist. 5, Can. 54, apud. SS. Benedict. XIV. de Sinod. Dioc., lib. 7, cap. 61, núm. 7, edit. Rom., 1748.

6 D. Cypr., Epist. 61 ad Euchr., p. 101, edit. Paris, 1726.

7 Véase la nota del fin de este cap.

8. Tertul., tom. 2, lib. De Spect., cap. 17, pp. 255 y 256, edit. Paris, 1584 .

9 Tertul., ibid., cap. 26, p. 258, lit, D.

10 D. August.; tom. 1, lib. 6, Conf., column. 126, lit. B, edit. Paris, 1689.

11 Salvian., lib. 6, De Gubetnat. Dei, in tom. 8, Biblioth. Vet. PP., p. 366. 'column. 2, lit. F, edit. Lugd., 1677.

12 Eccli. 22, v. 6.

13 Tertul., tom. 2, lib. De Spect., cap. 28, p. 258, lit. E, edit. Paris, 1584 .

14 Sit eis ad inhonesta convivia, vel spectacula sive curias, seu choteas accessus penitus interdictus. Histrionibus seu vanitatis intuitu nihil dent; et ne quidquam illis donetur a propria familia prohibere procutent. In Opusc., tom. 2, Regul. Tertiat., cap. 4, p. 225, edit. Antuerp., 1623; Vvading., ibid., tom. 2 .

15 Psalm. 92, v. ult.

16 Vvading. ad not., loc. cit.

17 S. August., tom. 3, p. 2, tract. 100, in 16 Joann., column. 749, n. 2, lit. B, edit. Paris, 1689.

18 D. Chrysost., tom. 7, hom. 6, in Matth., p. 100, n. 7, lit. A', edit. Paris, 1727.

19 Gasp. Hurt., disp. 173, De Scand., subsect. 10, \&371, p. 1577, edit. Salmant., 1631. (A1 parecer, el señor Obispo don Juan de Palafox y 
Mendoza confundió al Padre Gaspar Hurtado con el Padre Pedro Hurtado de Mendoza, cuya obra De Scand, disp. 173, Salmant, 1631, contiene estos pasajes relatívos al teatro. Escribió éste uno de lós alegatos más violentos contra el teatro. Véase Cotarelo y Mori, op. cit., pp. 362-364; Augustin et Aloys de Backer, Bibliothèque de la Compagnie de Jésus, nouvelle édition par Carlos Sommervogel, Bruxelles-Paris, 1893, IV, 532-535. Este error de nombres debe recordarse al leer las notas posteriores. Nota de Johnson.)

20 Gasp. Hurt., eod. loc., § 350, p. 1572.

21 Lipsius, tom. 2, lib. De Magnit. Rom., cap. 11, per tot., edit. Lugd., 1613.

22 Procopius Caesatiens., Anecdota Arcana Historia, qui est liber 9, Historiat., edit. Lugd., 1623.

23 Gasp. Hurt., disp. 173, De Scand., subsect, 7, § 350.

24 Idem., loc. cit., subsect. 11, de Permis. Comoed.

25 Volater. in Phill, lib. 29.

26 D. Cyprian., lib. De Spect., p. 339, edit. Paris, anno 1726.

27 Gasp. Hurt., loc. cit., disp. 137, subsect. 9, § 358, p. 1574.

28 Eccli. 3, v. 27.

29 D. Chrysost., tom. 1, hom, 1, in Psalm. 50, fol. 213, column. 4, edit. Venet., 1549.

30 Gasp. Hurt., disp. 137, De Scand, subsect. 8, $\$ 355$, p. 1573, edit. Salm.

31 Gasp. Hurt., ibid., subsect. 11, § 397, p. 1579.

32 Apoc. 2, v. $1 \& 3$, v. 1.

33 Psalm. 103, v. 4.

34 Caiet. in 6 Lucae, v. 13.

35 1. ad. Cor. 11, v. 22.

36 Tules está apropiado en lengua megicana a significar los concursos donde se juega a naypes y juegos prohibidos, aunque su significado primero es lo que llama el español espadañas.

37 Conc. Mexic., lib. 2, tit. 5, $\$ 1$ de Ludis, in tom. 4, Collect. Concit. per Eminent. Aguirre, p. 342, edit. Rom., 1693.

38 Pius V, Greg. XIII, Clem. VIII in Bulla: Suscepti munetis, apud Rodrig., tom. 3, Quaest. Regul., quaest. 68; Cap. Qui venatoribus, 1 y 2, distinct. 86, D. Aug., ibi relatus.

39 Nahuyaque es una especie de víbora que tiene la cabeza más grande. 
